\title{
Accreditation of University Students to the New Media at the Time of Political Crises
}

(Field study on a sample of students of the Faculty of Arts، Salahuddin University)

\author{
Dr. Sadiq Hama Gharib Hama Salih
}

\begin{abstract}
Media has passed a lot of stages from its beginning until now، many big revolutions had happened in growth and improvement in which each one distinguishes the specializations and duties of the previous one. The most important stage is the development of a style of Media which is called (New Media)، which depends on new technologies such as Computer and internet for performing functions and activities of Media.

New Media by its modern meaning in Kurdistan region of Iraq returns to the time at which internet became available at the end of the last century. This kind of media is similar to the classic media (newspaper, radio، television), compared with the countries of the area، and even in the countries that have glory and leadership this kind of media didn't come late. It improved and grew faster and wider. And this was because of that openness after the freedom of Kurdistan/Iraq since 1991.early after this internet webs and electronic articles became part of communication and delivery articles.

This research is a scientific attempt to be careful of the quantity of the dependence of young people especially the students of Salahaddin University on this kind of media، and its effects on their aims، opinions and their thoughts. And the level of their trust on it during political crisis in the region of Kurdistan. Researcher highlighted young people because they are active and conscious. They are in a developing stage of knowledge and they develop their personality. This layer of society is considered as the dynamo of big changes in most countries and societies. They follow up things and they try to understand the changes that happen in their environment، and articles of media allow this to happen.
\end{abstract}

DOI: $10.33193 /$ JALHSS.38.15 


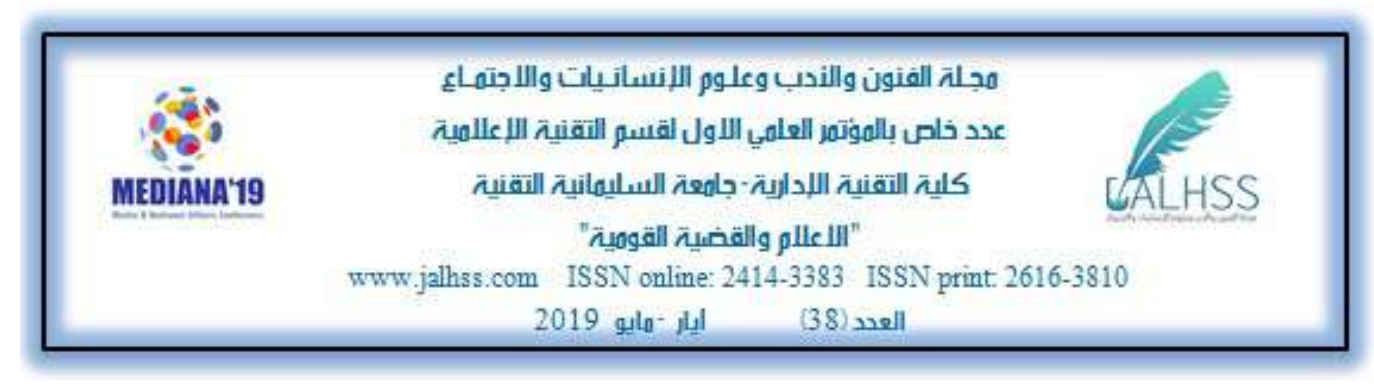

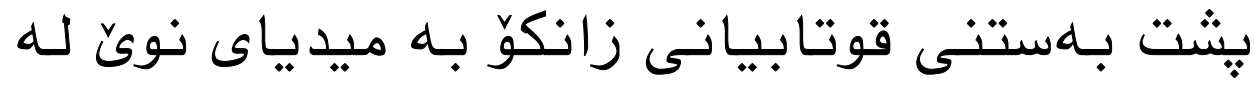

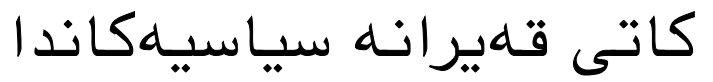

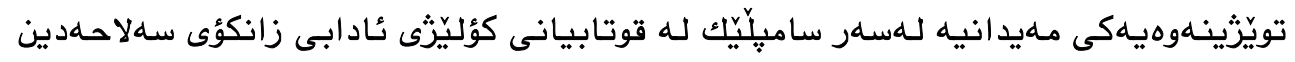

\author{
د . صادق حمـهغريب حمـهصالّح
}

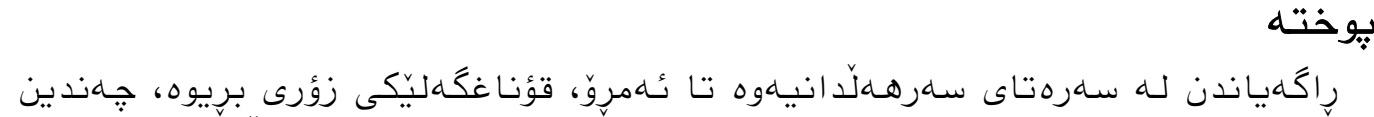

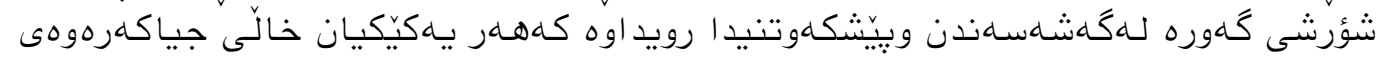

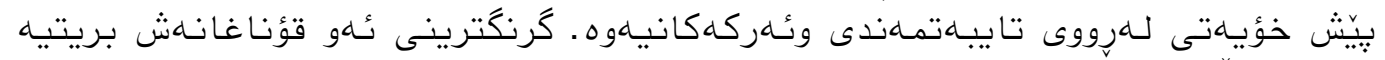

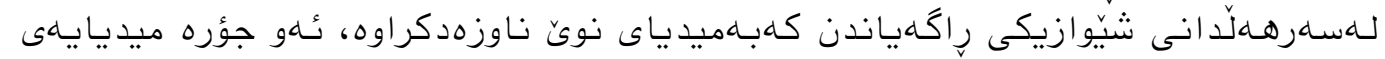

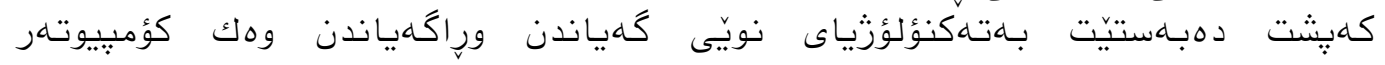

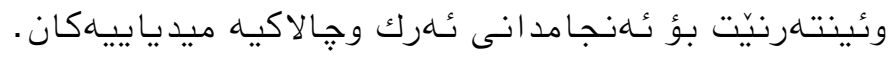

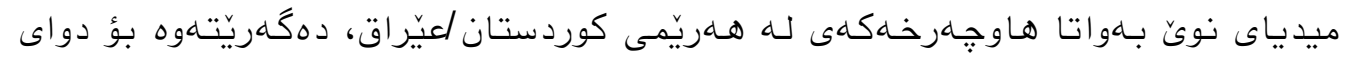

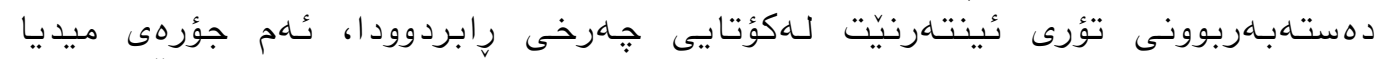

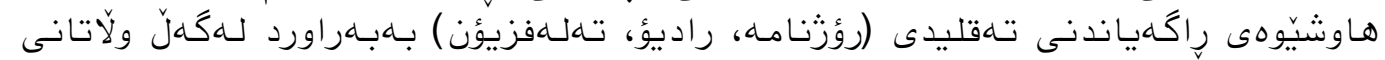

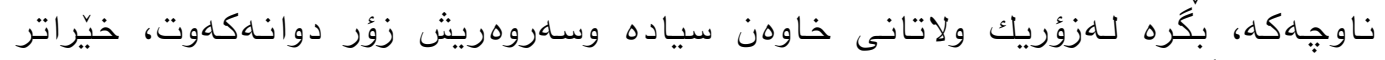

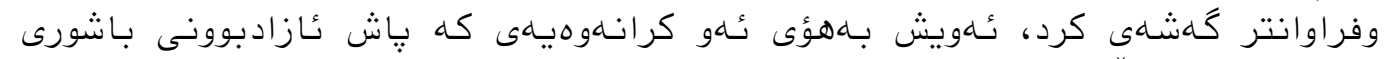

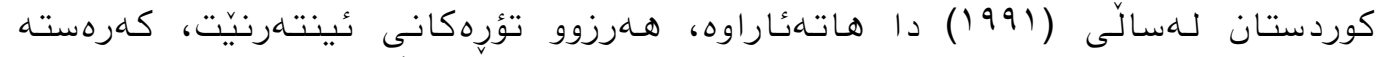

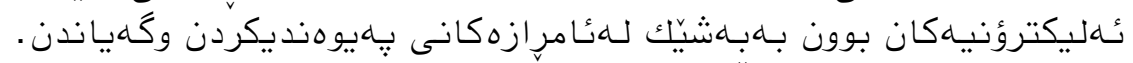

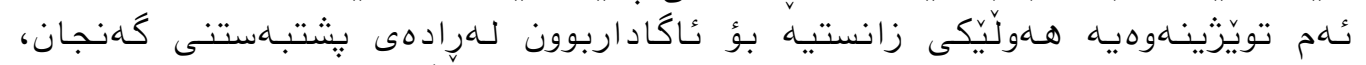

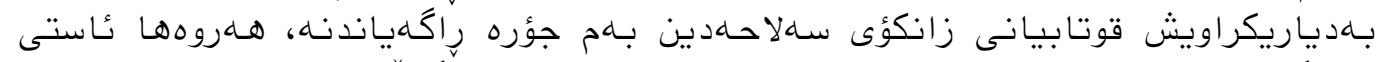

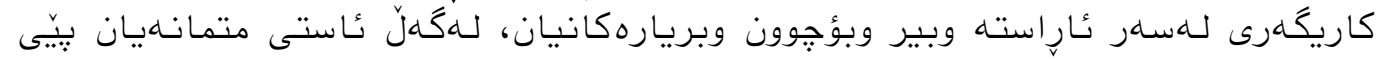

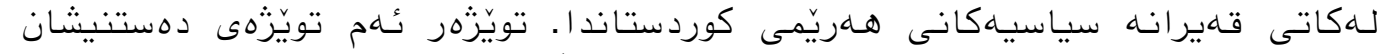

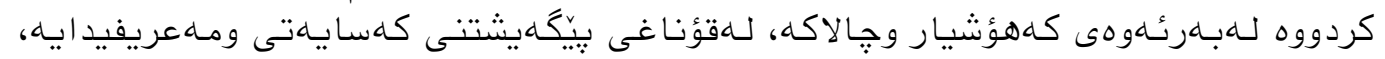

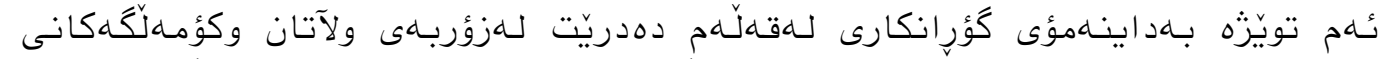

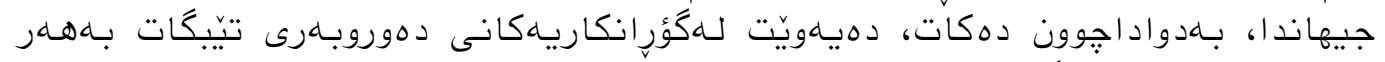

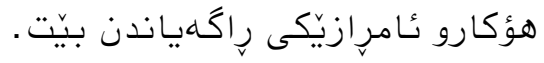

DOI: $10.33193 /$ JALHSS.38.15 


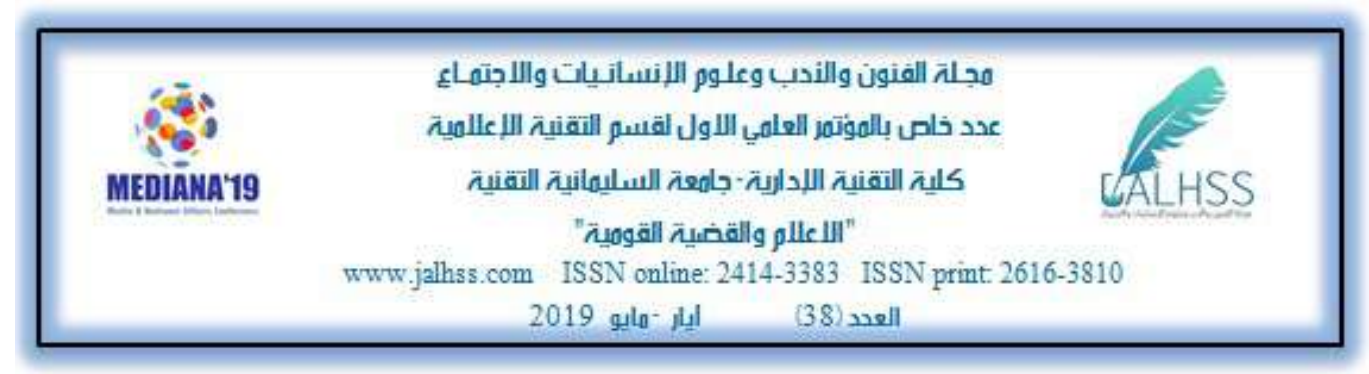

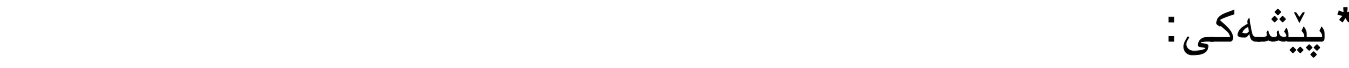

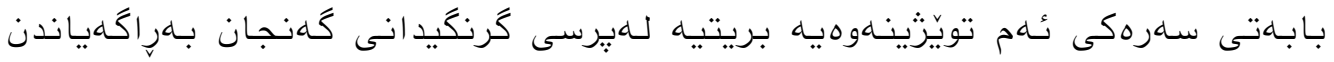

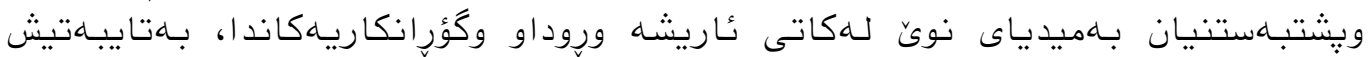

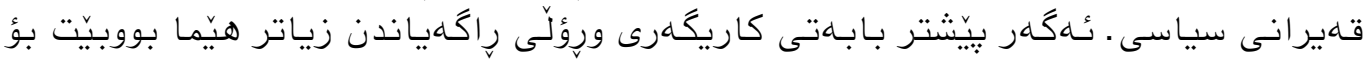

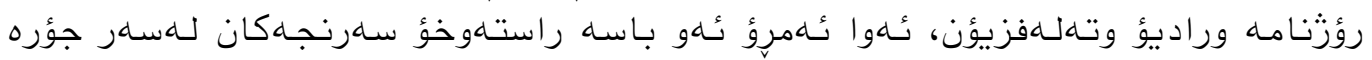

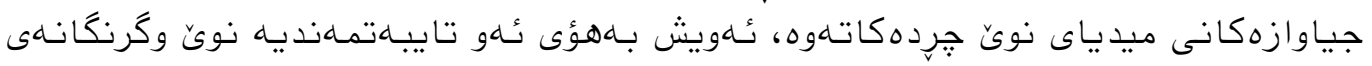

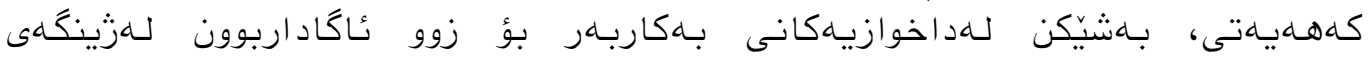

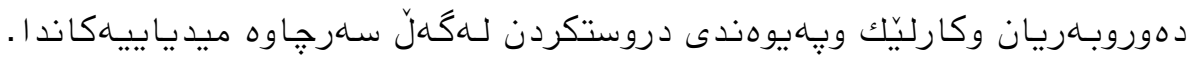

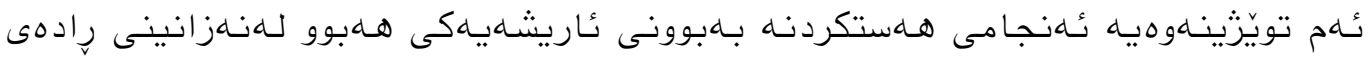

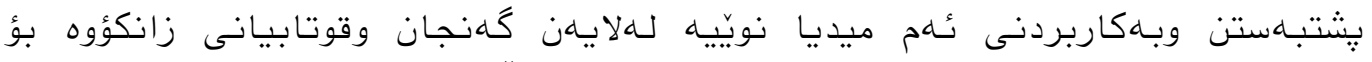

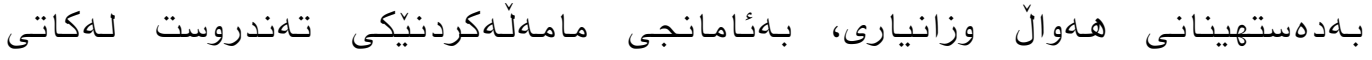

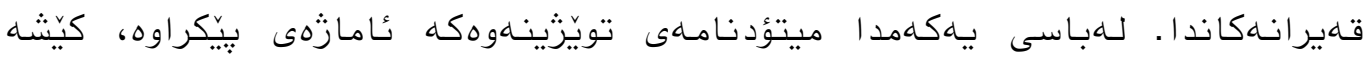

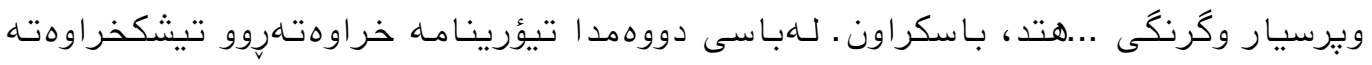

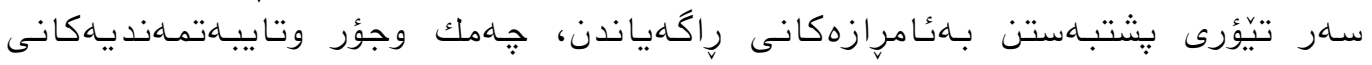

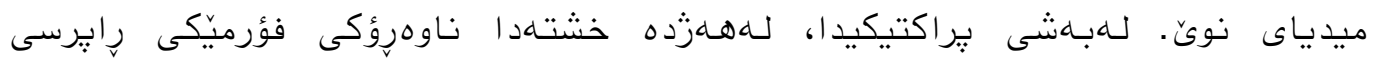

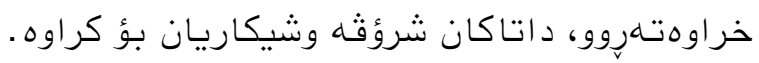

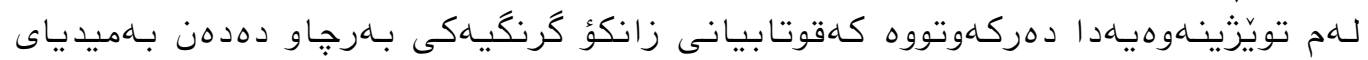

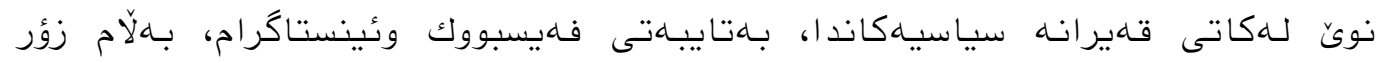

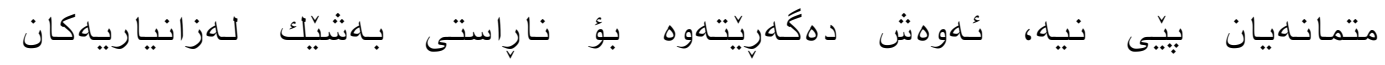

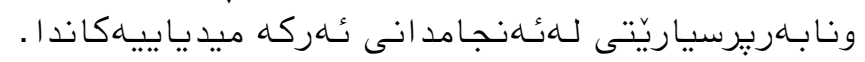




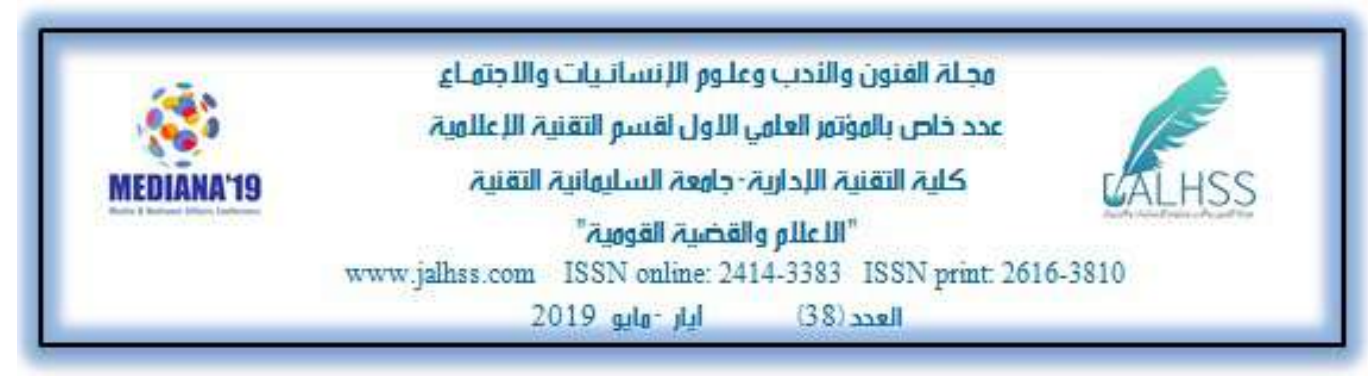

- باسى يلهكم: ميتؤدنامه -

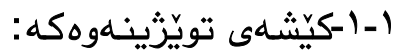

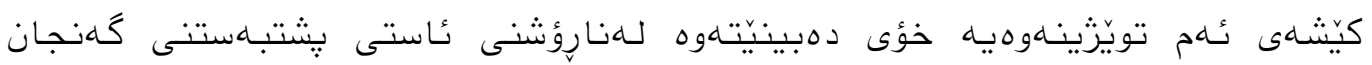

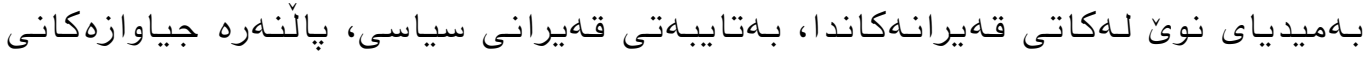

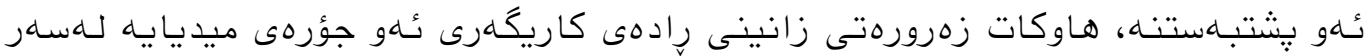

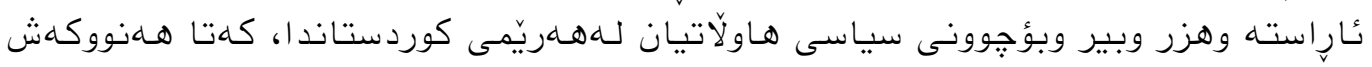

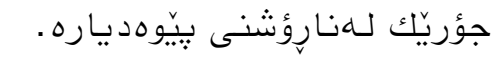

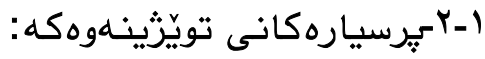

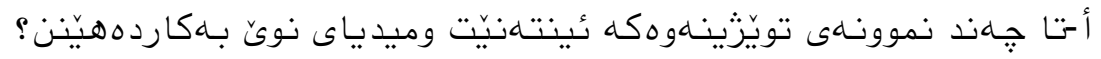

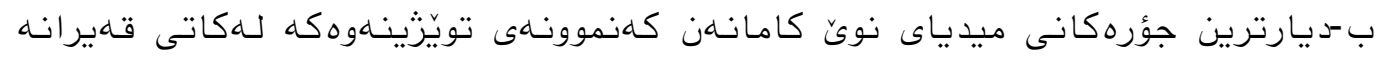

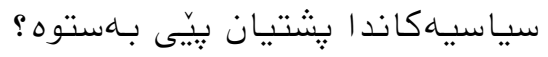

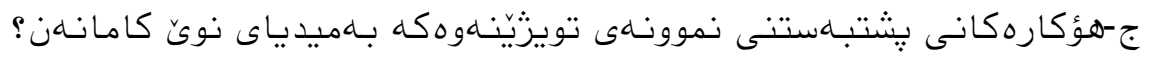

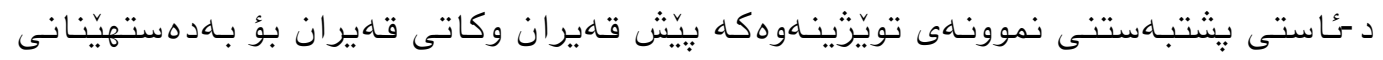

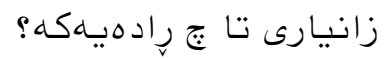

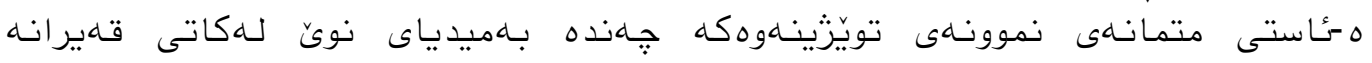

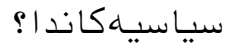

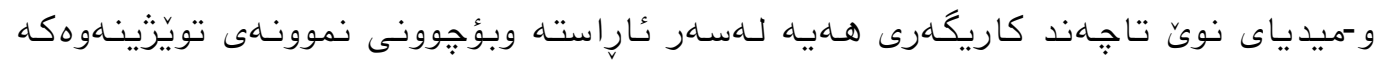

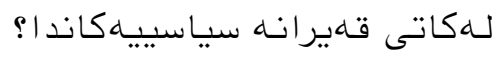

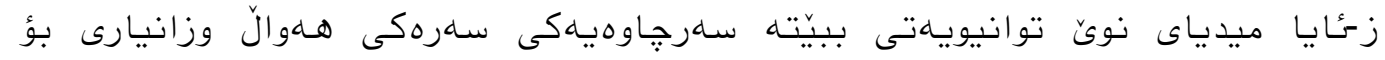

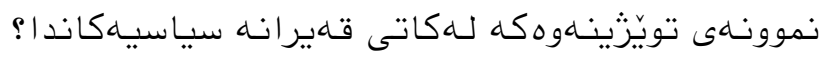

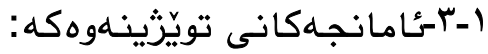

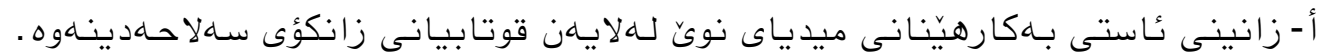

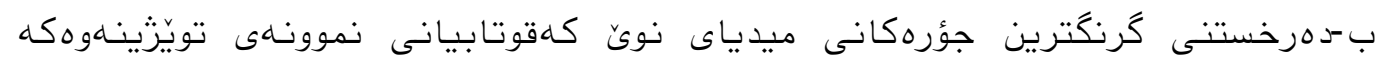

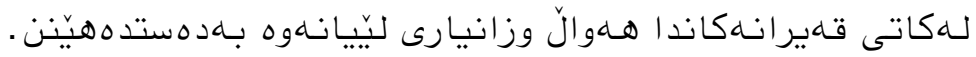

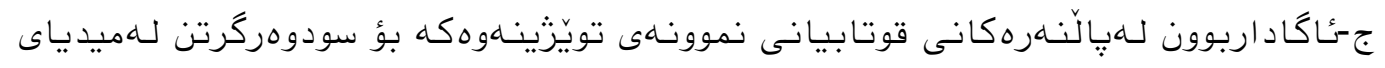

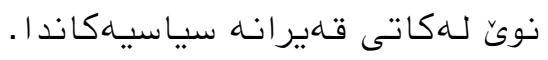

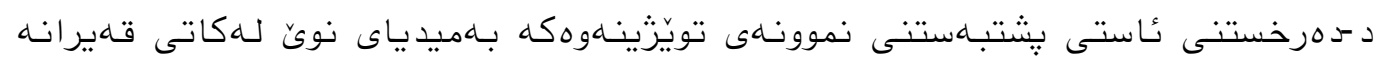
سياسيهكاندا.

372

DOI: $10.33193 /$ JALHSS.38.15 


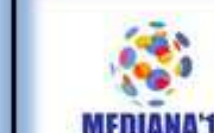

مج لم الفنون والندب وعلوم اللانسانيات واللاجتهـاءع

عدد خلم بالموتتمر العامي اللاول لقسم التقنية اللاعلامية

كلية التقنية اللداريت-جامعت السليمانية التقنية

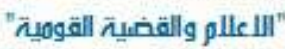

www.jalhss.com ISSN online: 2414-3383 ISSN print 2616-3810

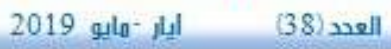

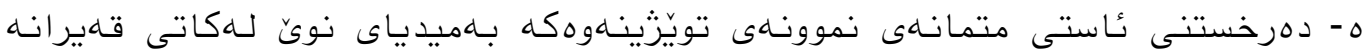
سياسيه كاند ا.

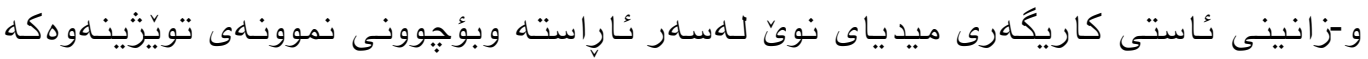
لهكاتى قلهيرانه سياسييهكاندا ا.

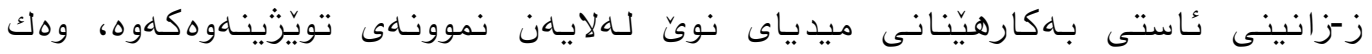

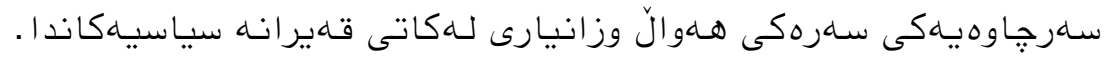

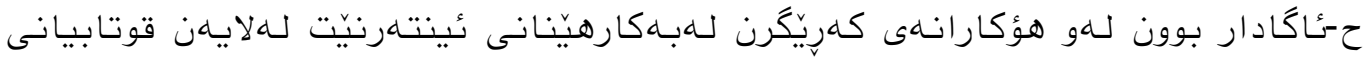
نموونهاى تويَزْينهاهوه كهوه

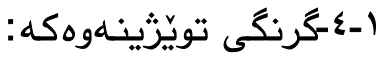

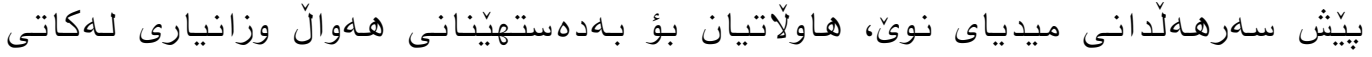

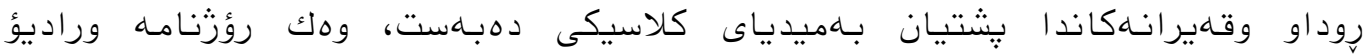

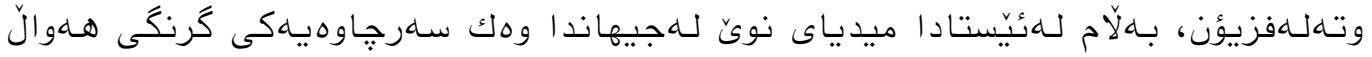

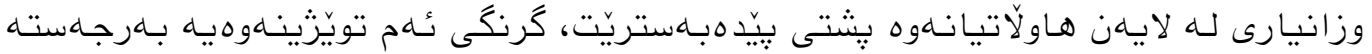

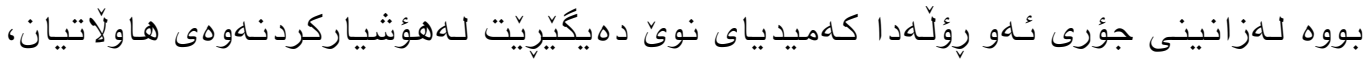

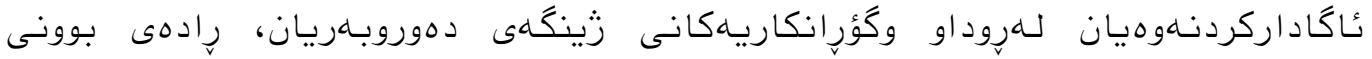

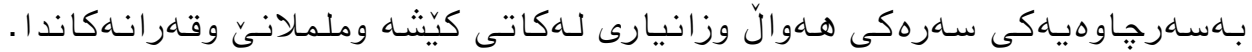

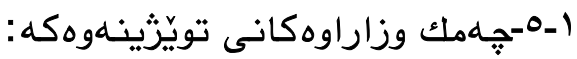

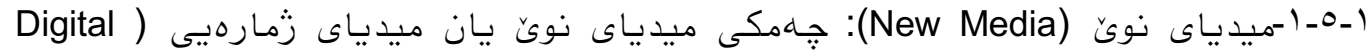
هedia

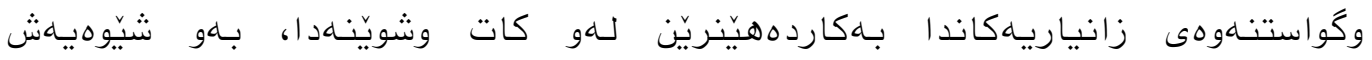

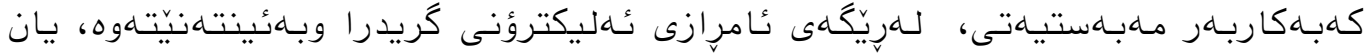

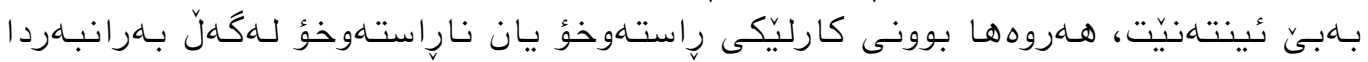

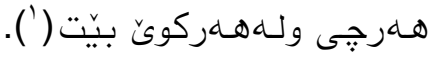

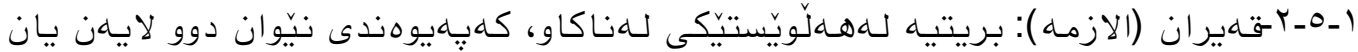

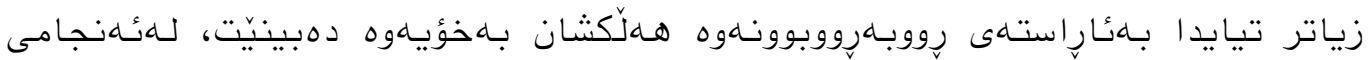

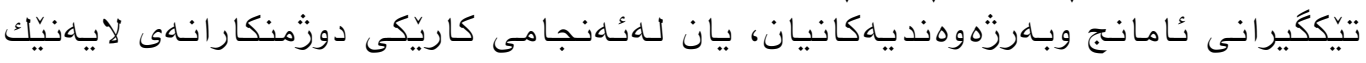

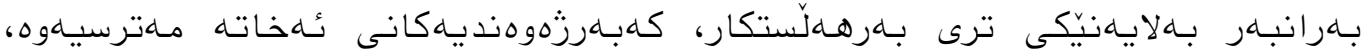

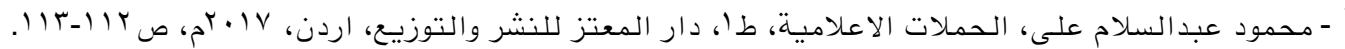

DOI: $10.33193 /$ JALHSS.38.15 


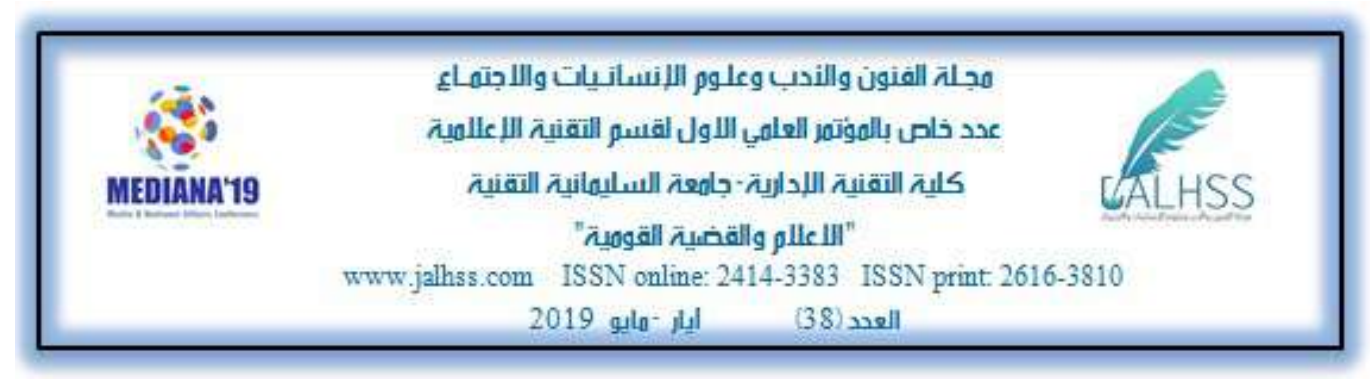

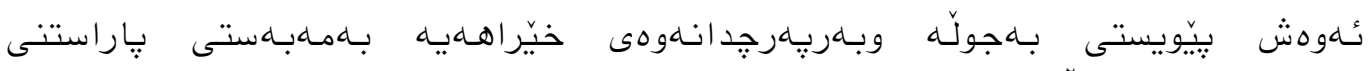

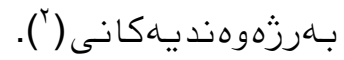

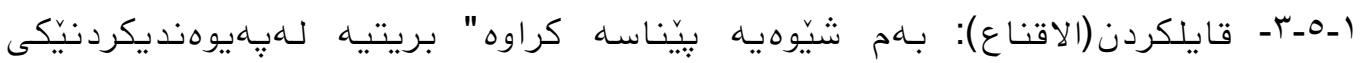

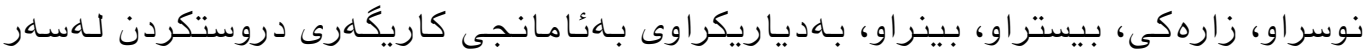

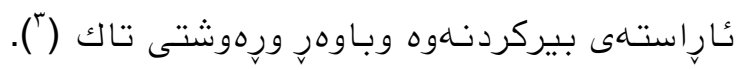

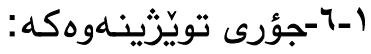

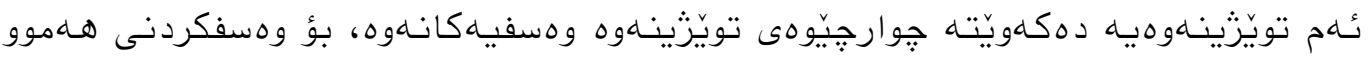

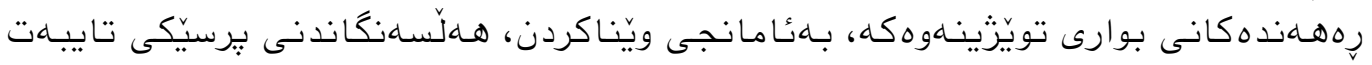

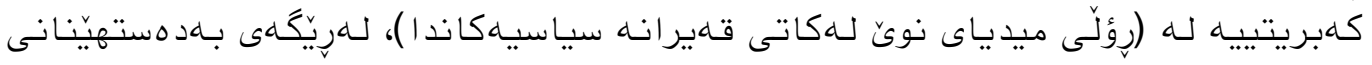

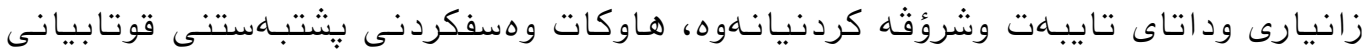

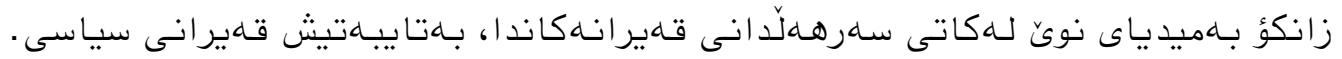

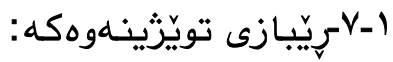

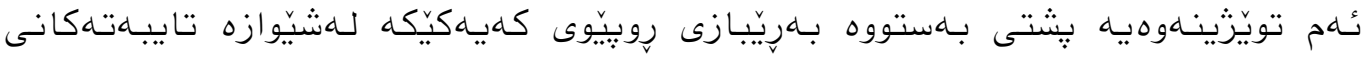

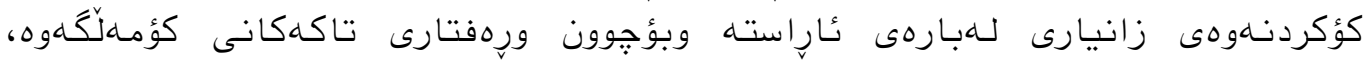

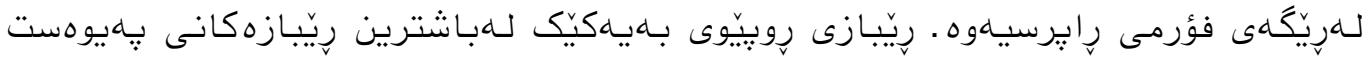

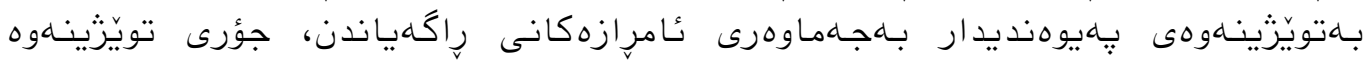

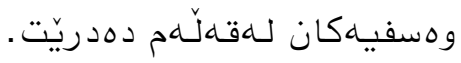
S-1

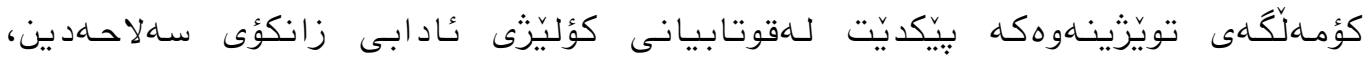

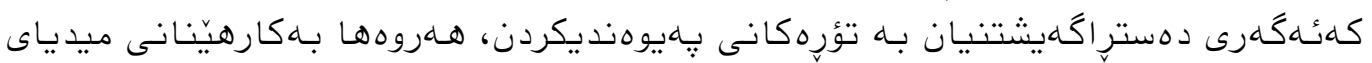

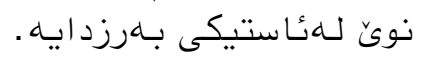

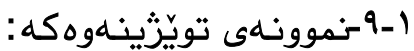

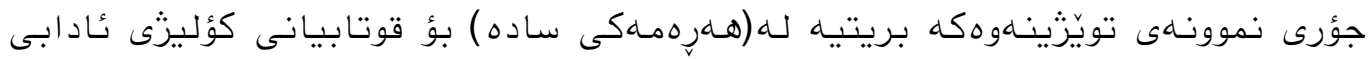

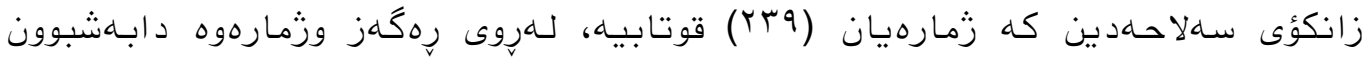

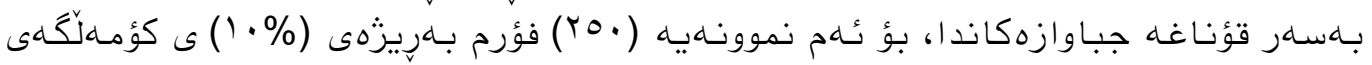

\footnotetext{
' - عبد العزيز بن صالح بن سلمهة، التخطيط الاعلامي ودوره في مواجهة الكوارث و الازمات، رسالة ماجستير،

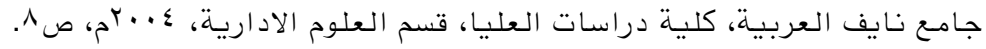

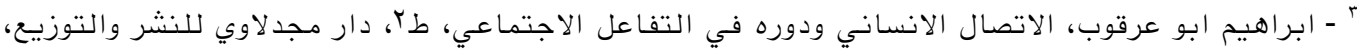

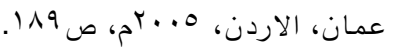

DOI: $10.33193 /$ JALHSS.38.15 


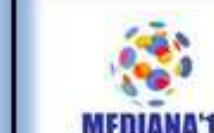

مجل الم الفون والندب وعلوم اللانسانيات واللاجتهاءع

عدد خلم بالموتتمر العامي اللاول لقسم التقنية اللاعلامية

كلية التقنية اللدارية-جامعة السليمانية التقنية

"

www.jalhss.com ISSN online: 2414-3383 ISSN print 2616-3810

2019 العيد

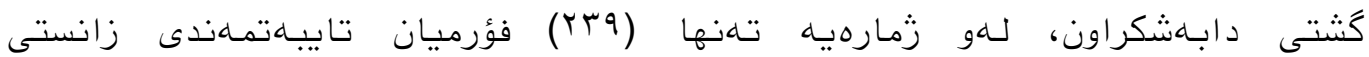

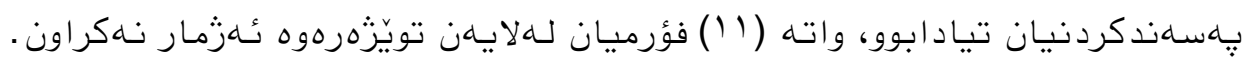

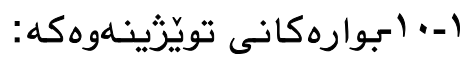

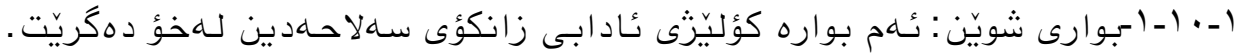

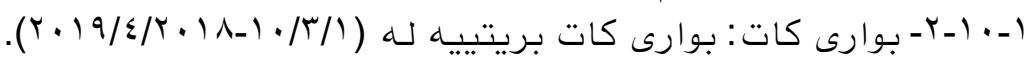

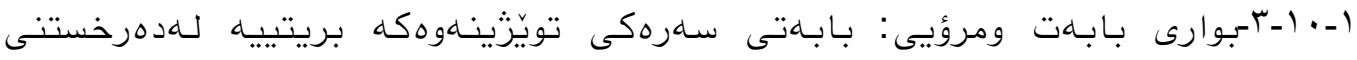

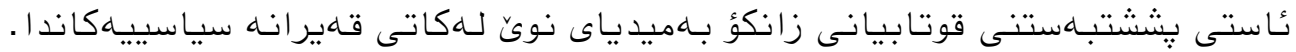

\section{- باسى دووهم: تبؤرينامهـ -}

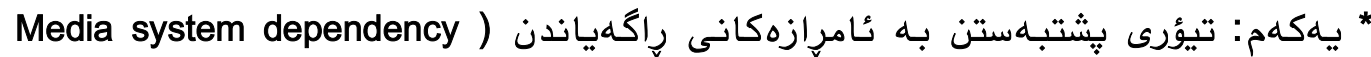

:(Theory

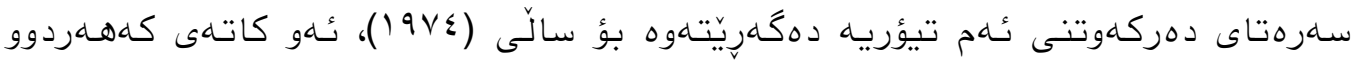

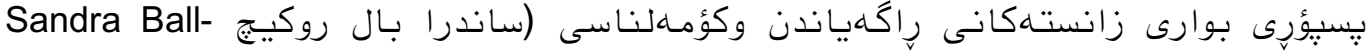
(Rokeach

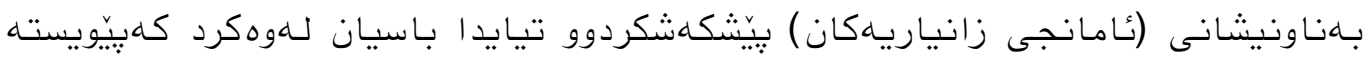

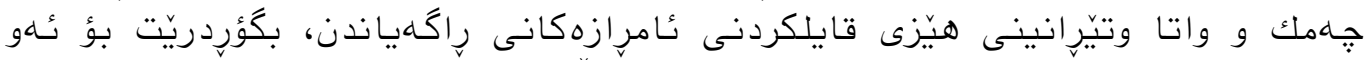

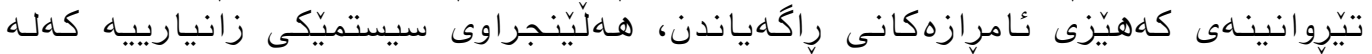

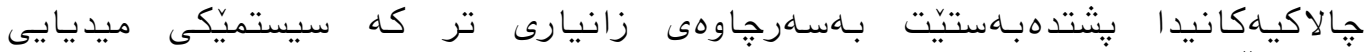

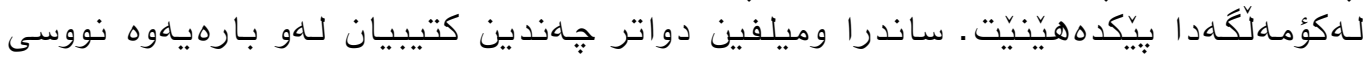

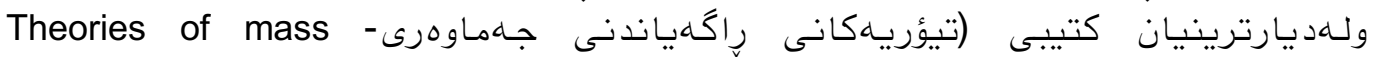

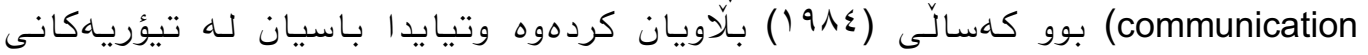

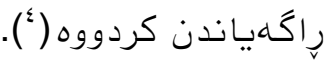

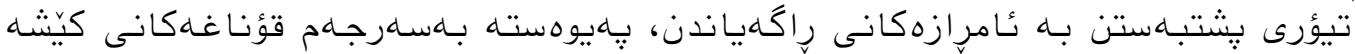

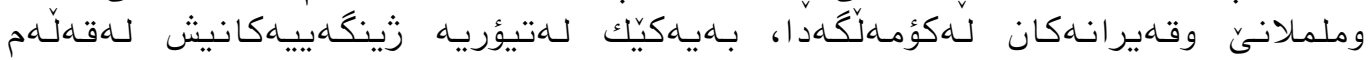

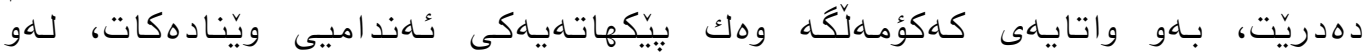

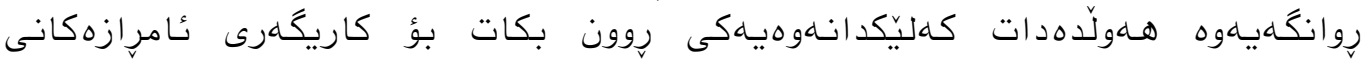

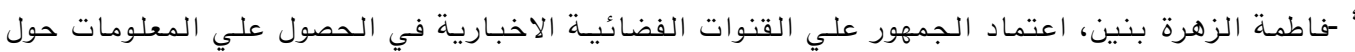

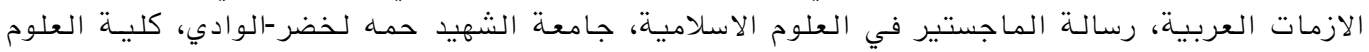

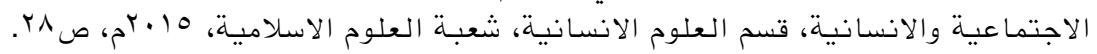

DOI: $10.33193 /$ JALHSS.38.15 


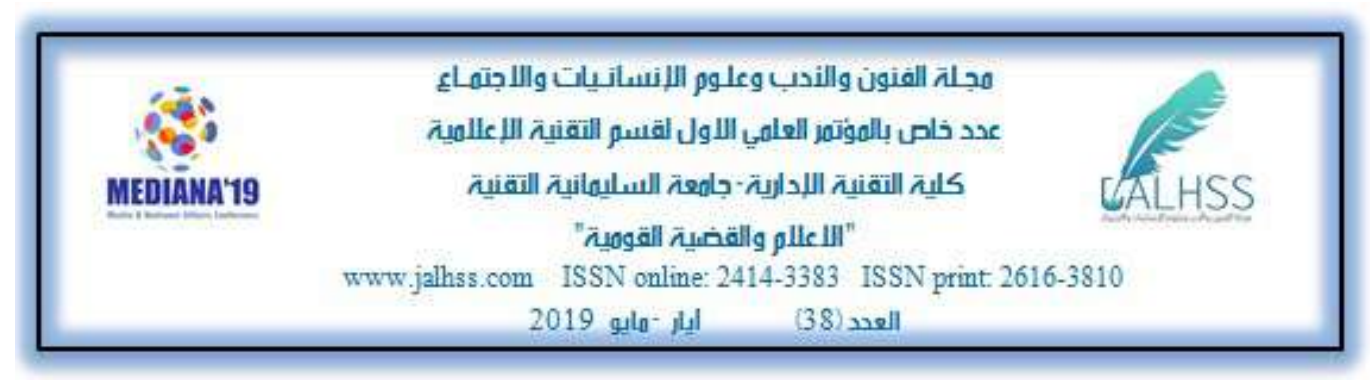

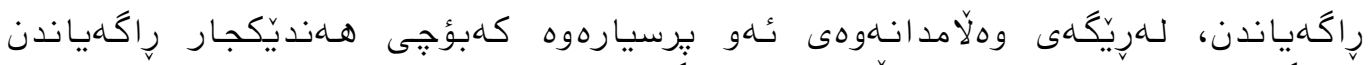

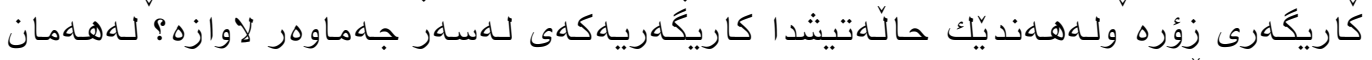

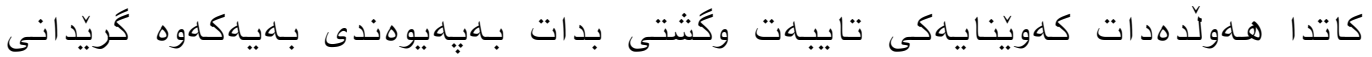

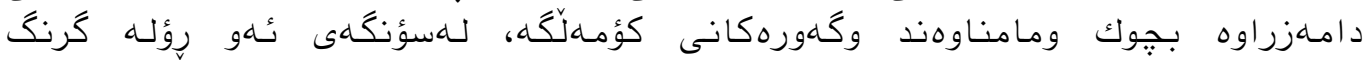

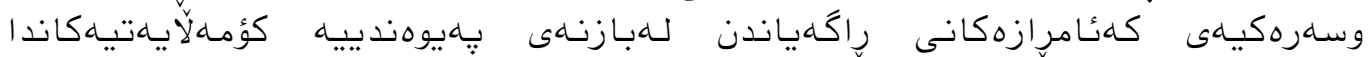

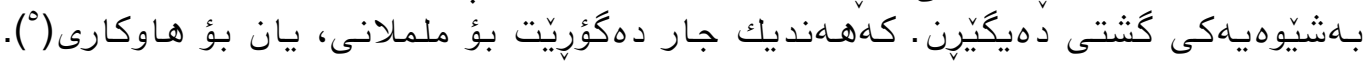

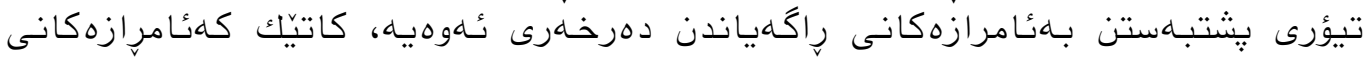

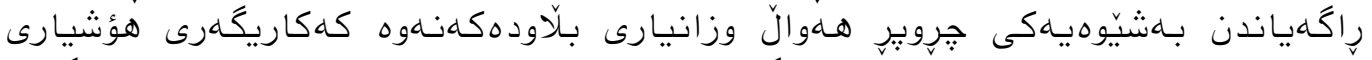

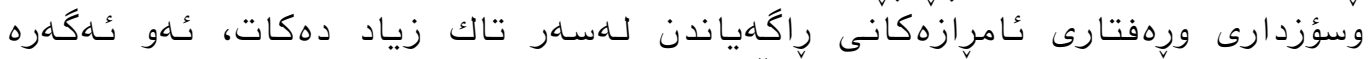

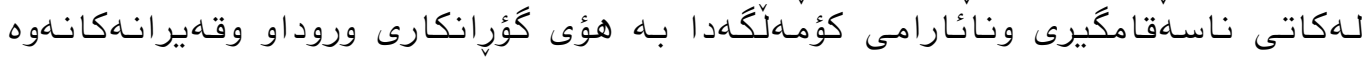

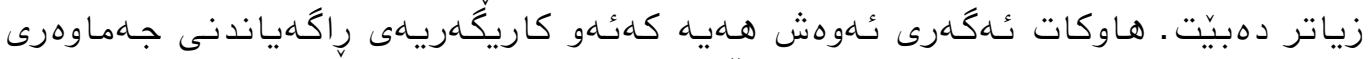

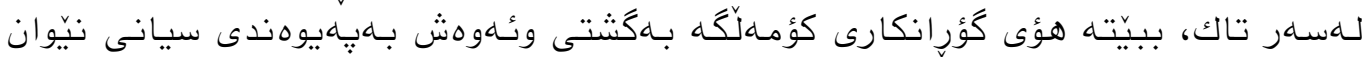

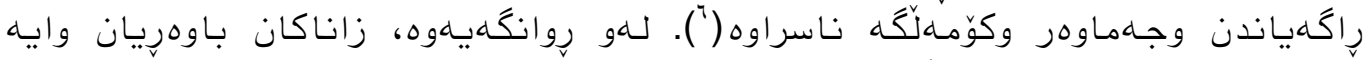

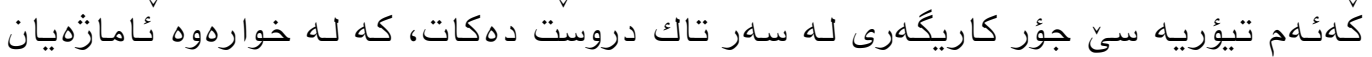

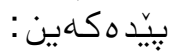

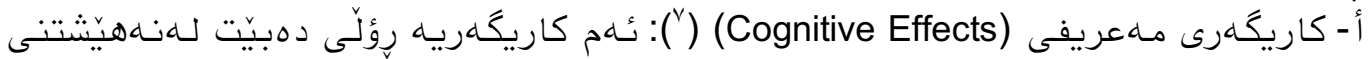

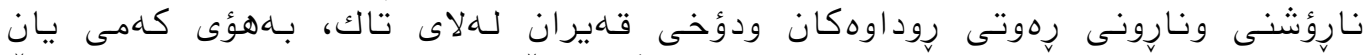

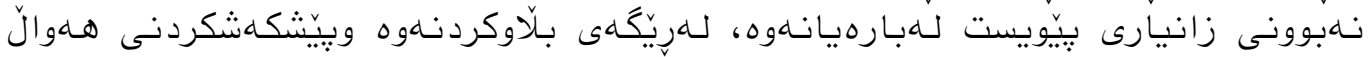

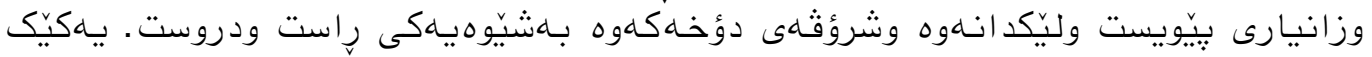

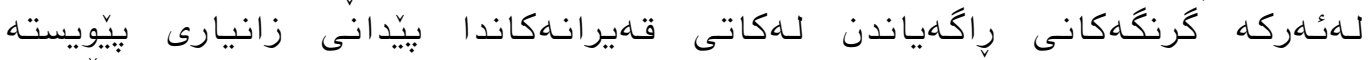

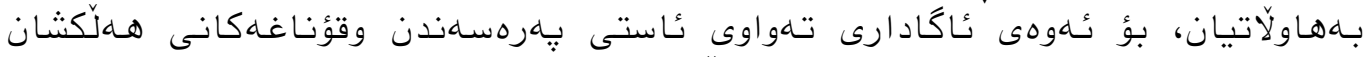

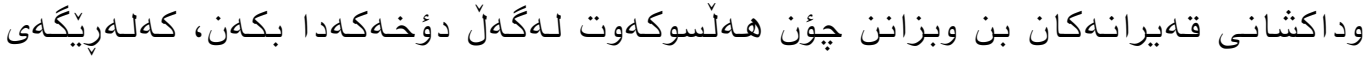

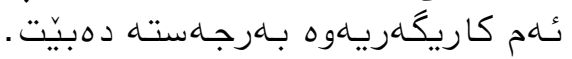

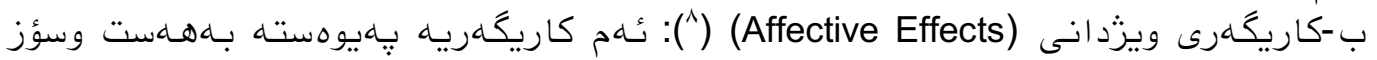

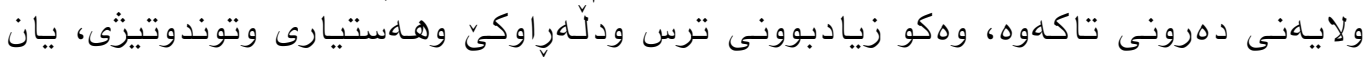

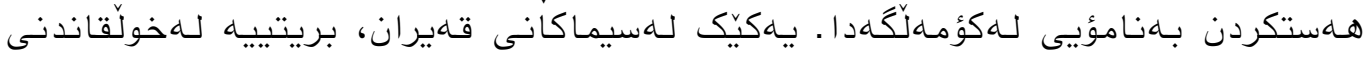

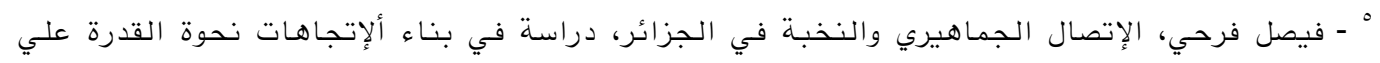

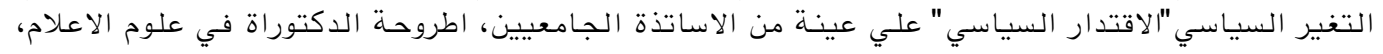

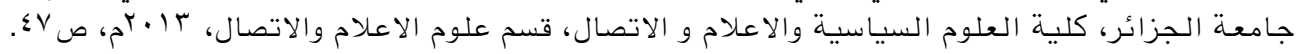

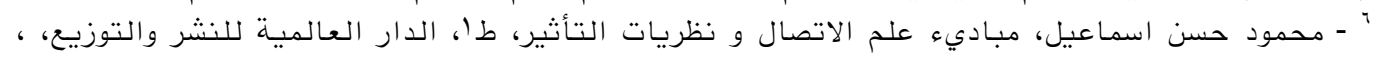

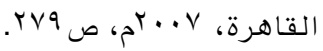

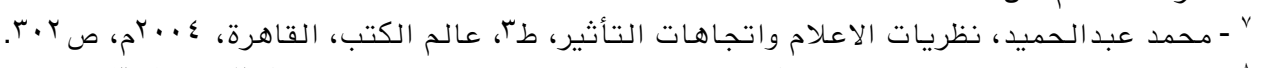

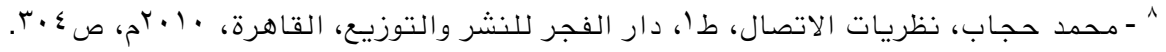

DOI: $10.33193 /$ JALHSS.38.15 


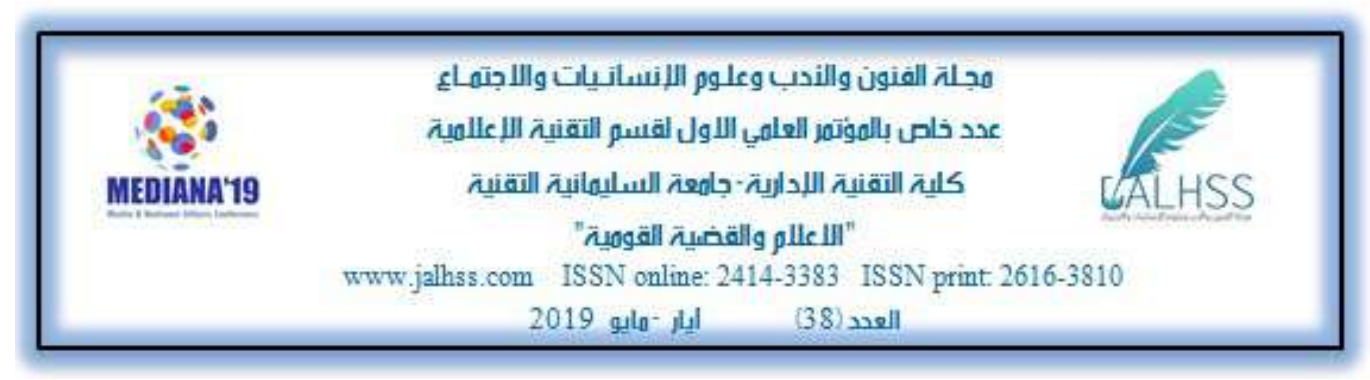

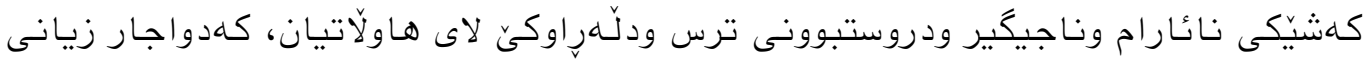

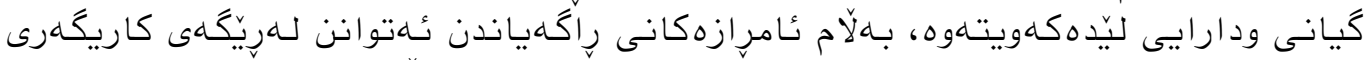

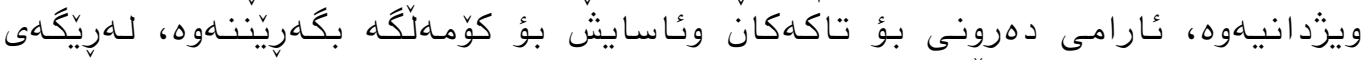

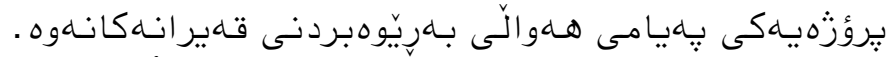

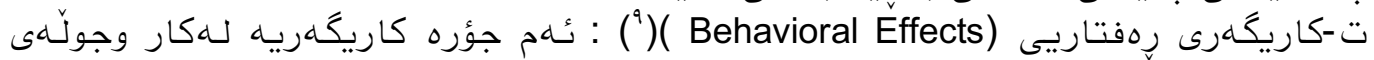

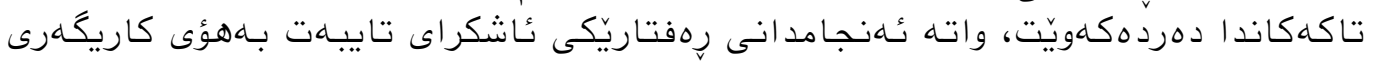

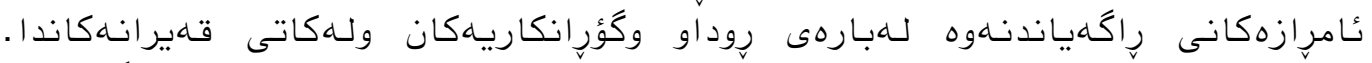

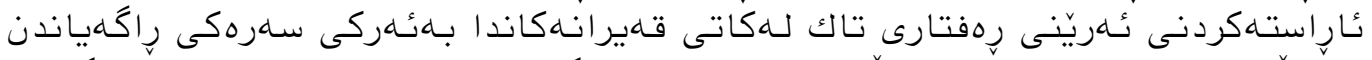

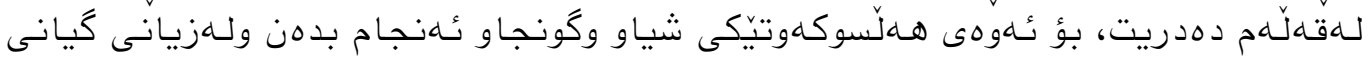

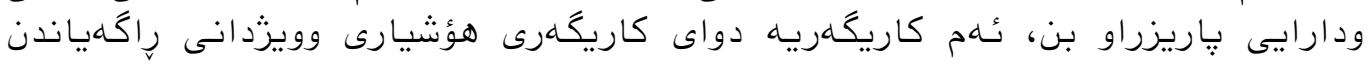

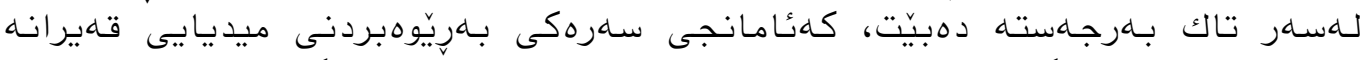

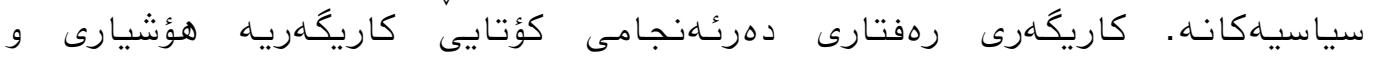

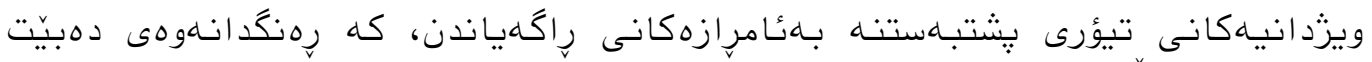

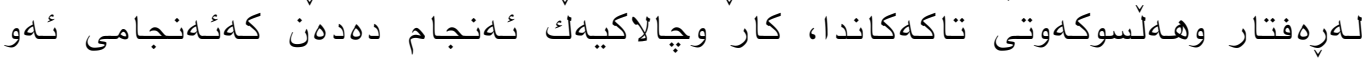

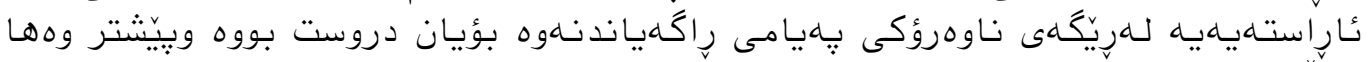

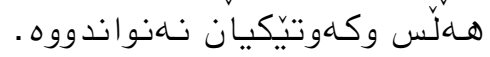

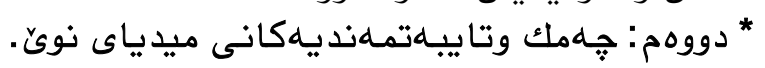

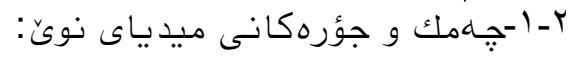

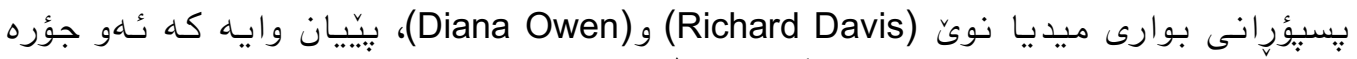

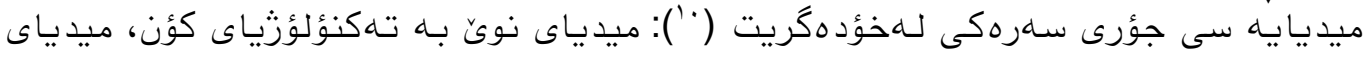

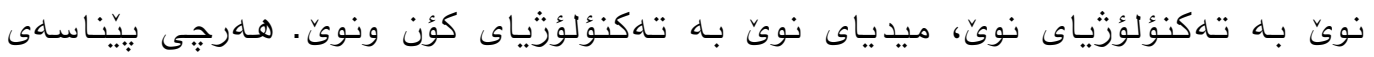

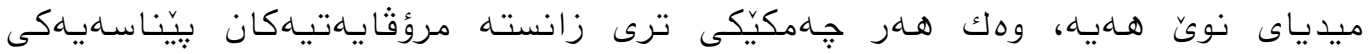

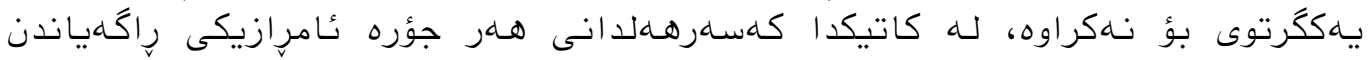

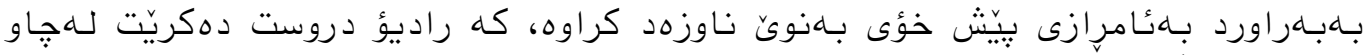

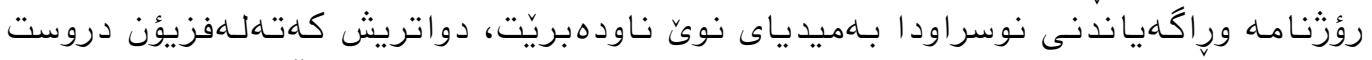

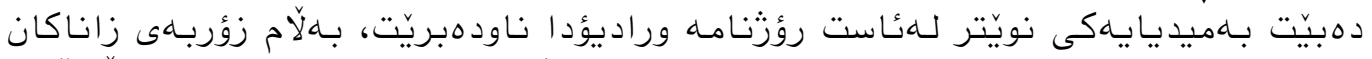

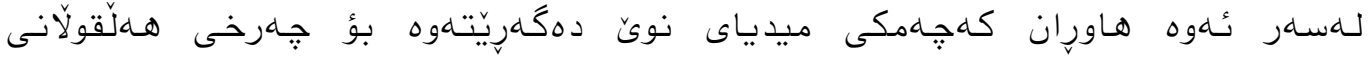

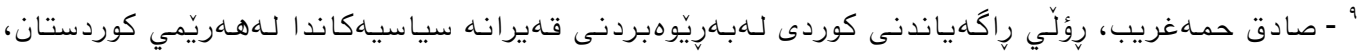

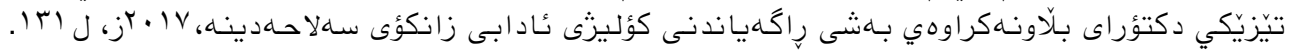

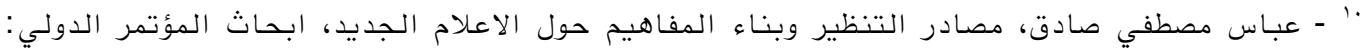

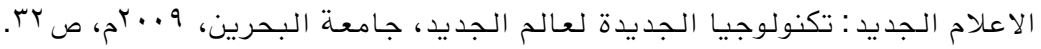

DOI: $10.33193 /$ JALHSS.38.15 


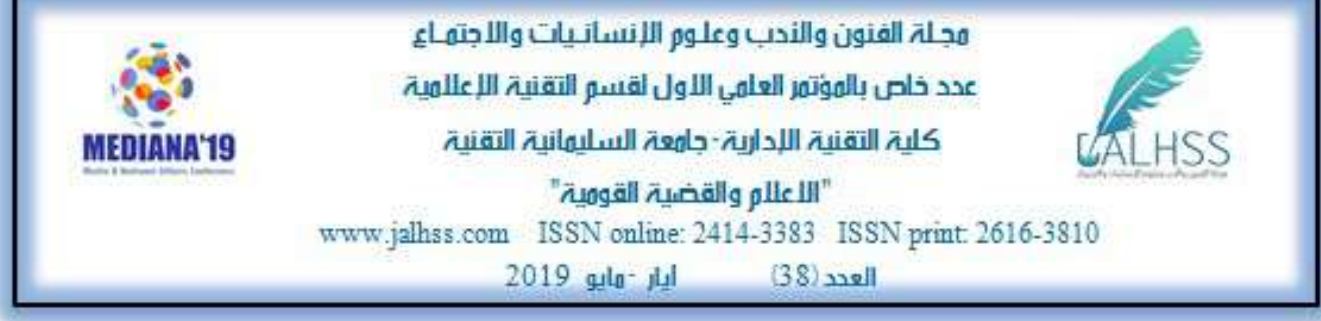

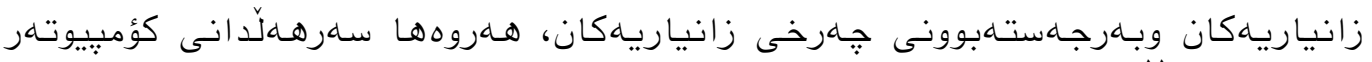

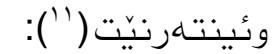

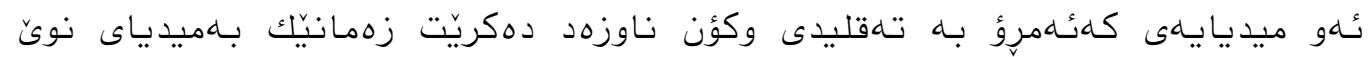

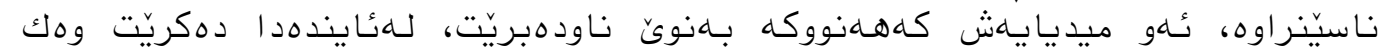

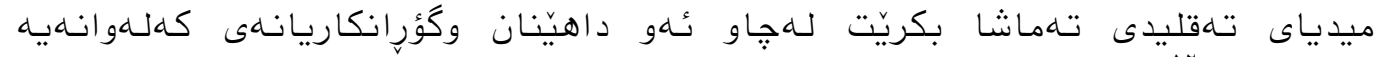

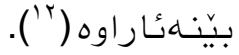

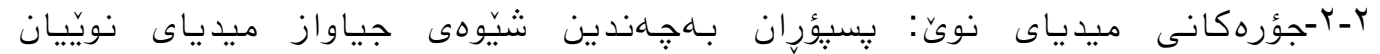

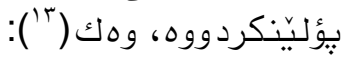

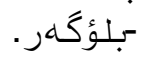

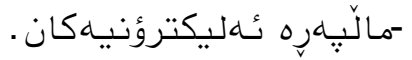

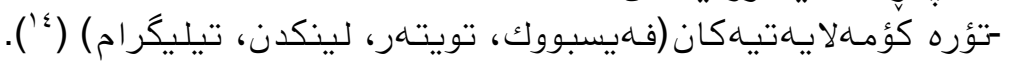

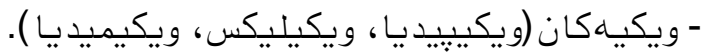

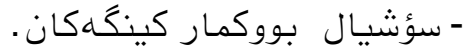

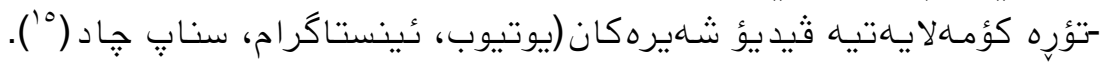

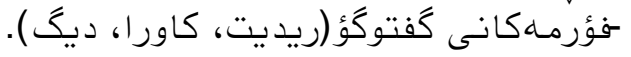

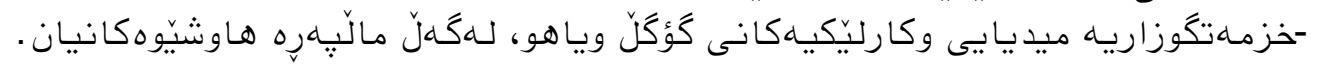

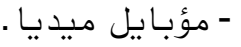

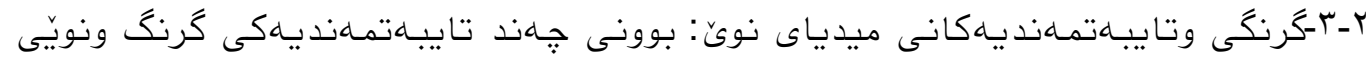

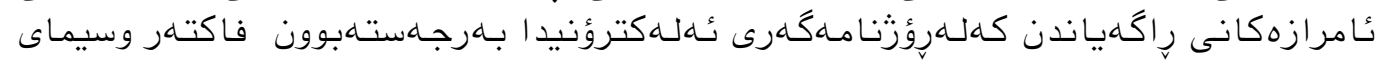

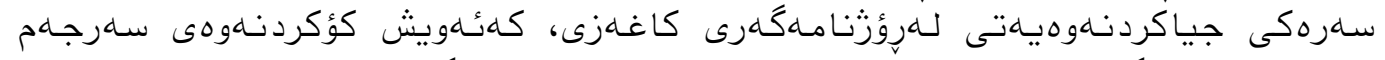

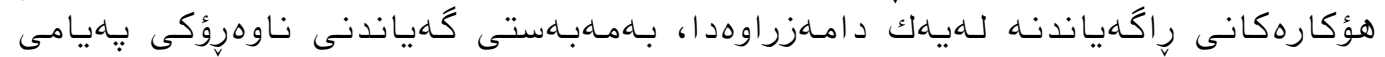

- سميره شيخانى، الاعلام الجديد فى عصر المعلومات، مجلة جامعة دمشق، المجلدابr، العدد

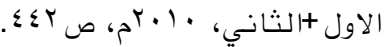

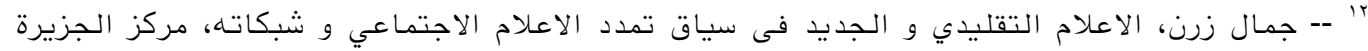

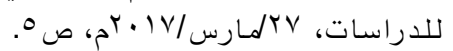
13 - Dan Gilmor، We The Media، 2003 ، p71.

14 - Linda Weiser Friedman، Hershey H. Friedman ، THE NEW MEDIA TECHNOLOGIES: OVERVIEW AND RESEARCH FRAMEWORK، Baruch College and the Graduate Center of the City University of New York، April 2008، p3.

$$
\text { "ا - الاعلام يصنع التغير، المجلة الالكترونية يو اس ايه، المجلد با، العدد با، ص^. }
$$

DOI: $10.33193 /$ JALHSS.38.15 


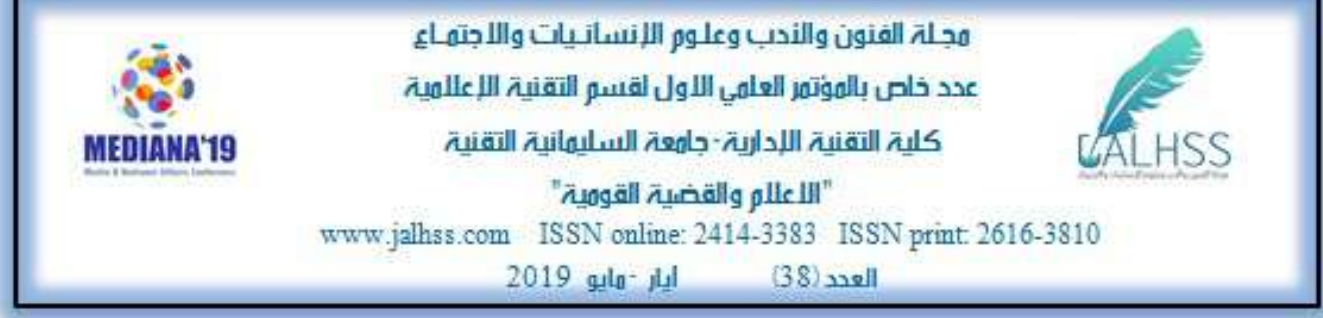

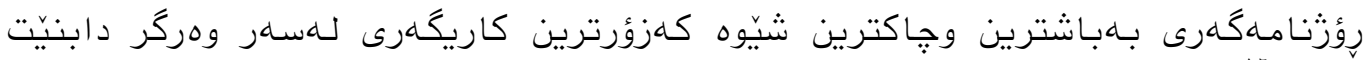
وهك (17)

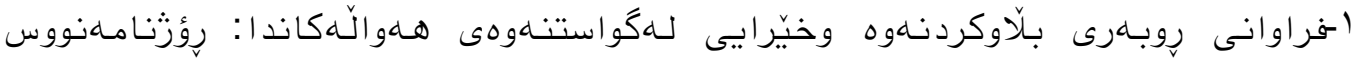

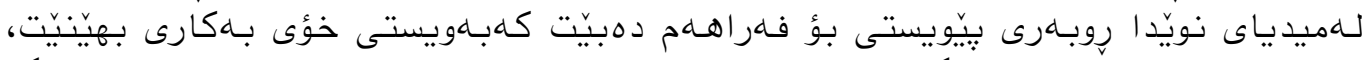

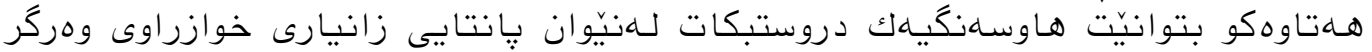

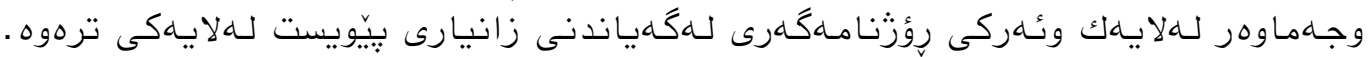

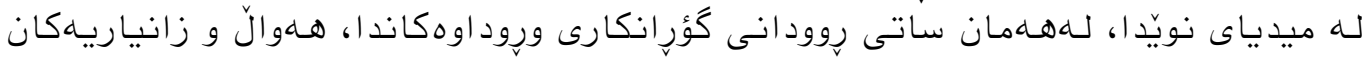

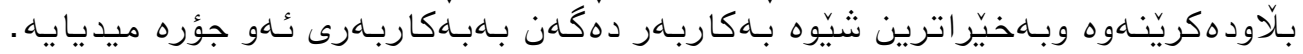

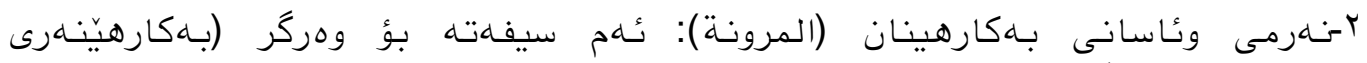

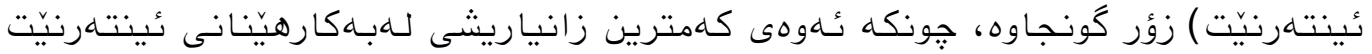

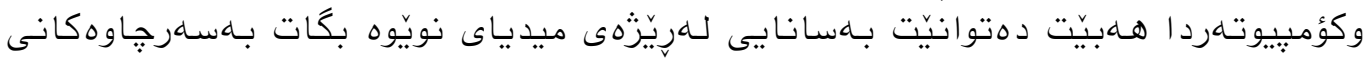
وسودى ليَّوهربكَريَّت

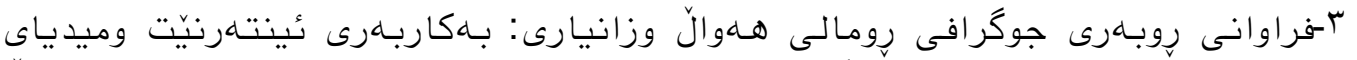

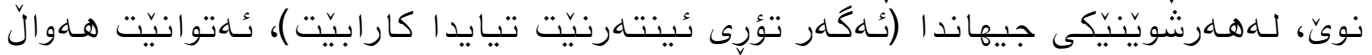

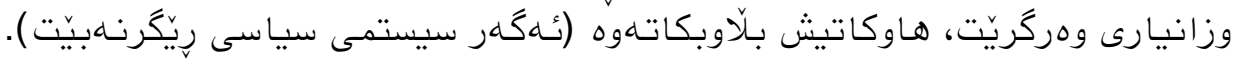

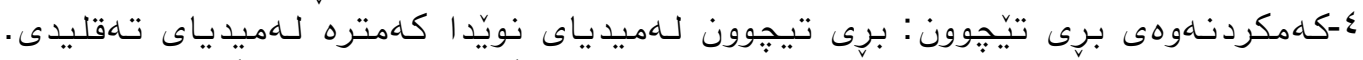

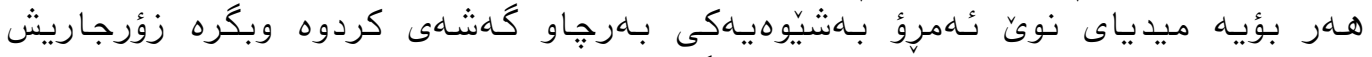

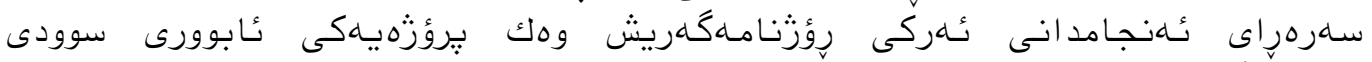

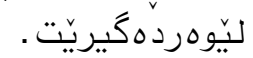

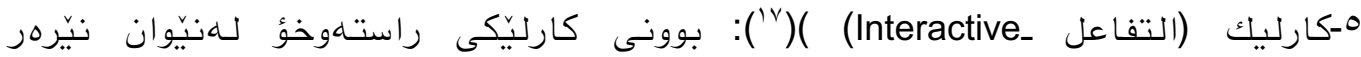

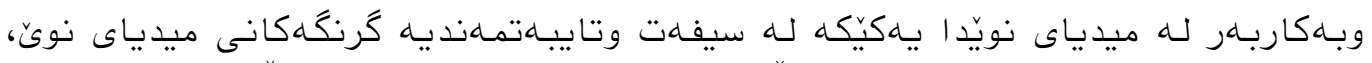

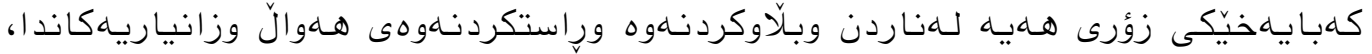
وهك

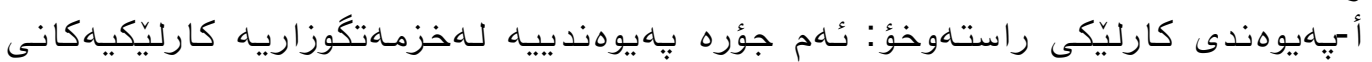

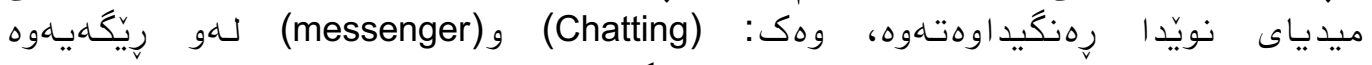

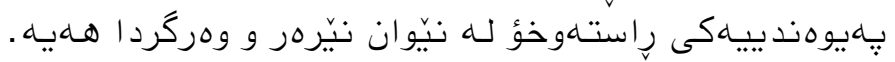

"' - حسن عماد مكاوى ومحمود سليمان علم الدين، تكنولوجيا المعلومات والاتصال، مركز التوزيع، جامعة

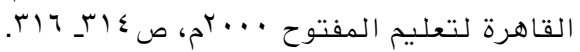

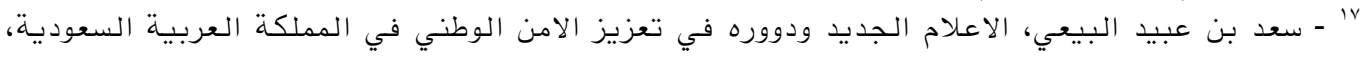

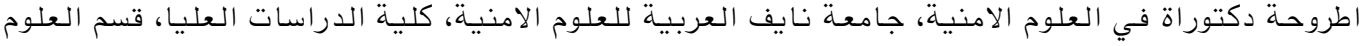

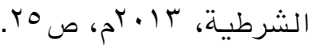

DOI: $10.33193 /$ JALHSS.38.15 


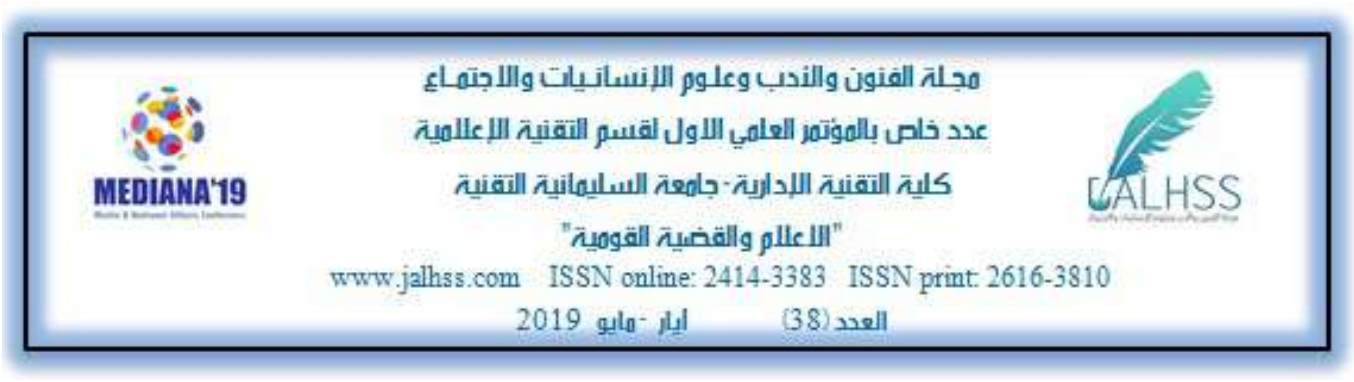

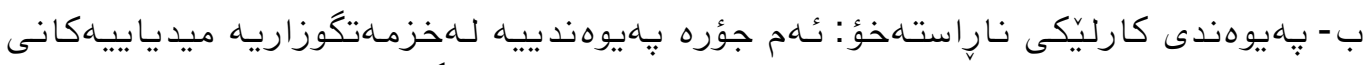

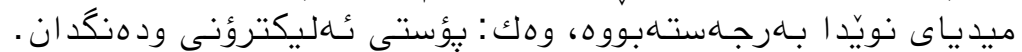

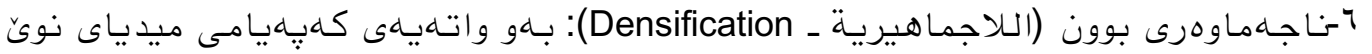

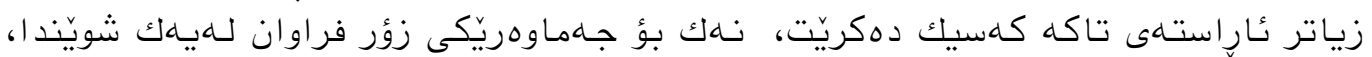

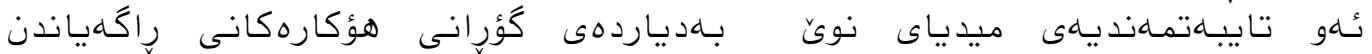

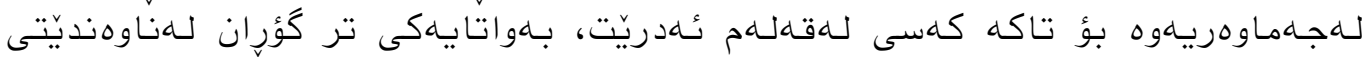

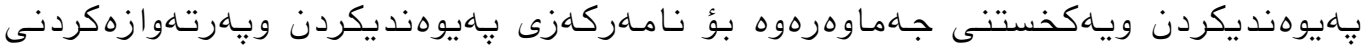

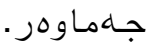

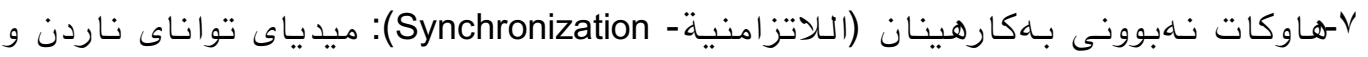

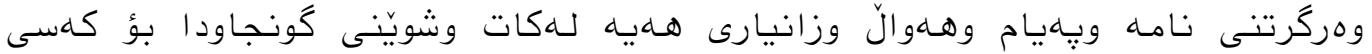

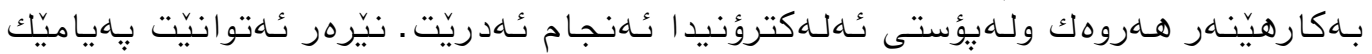

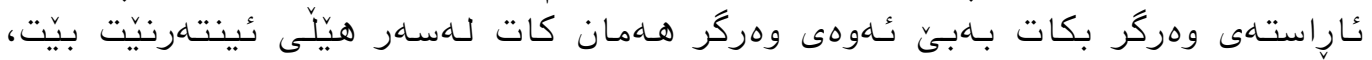

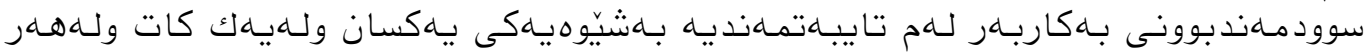

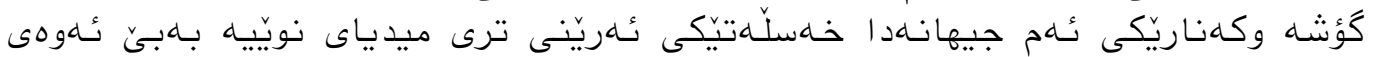

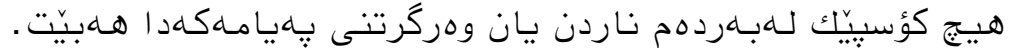

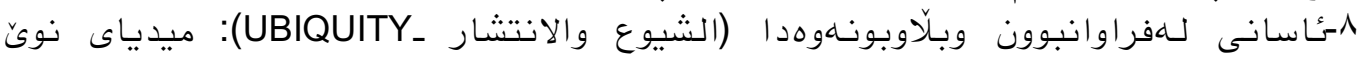

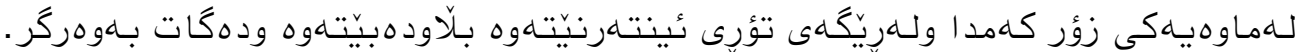

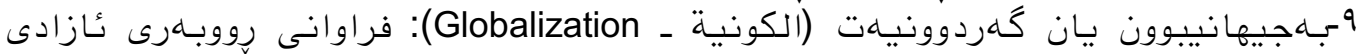

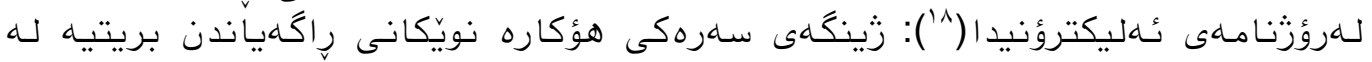

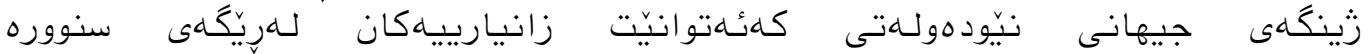

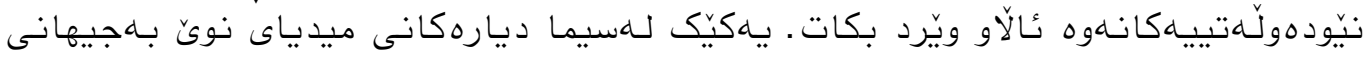

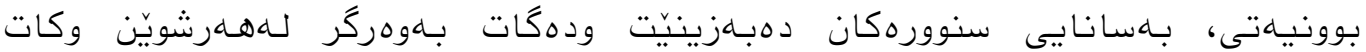

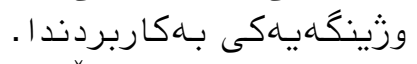

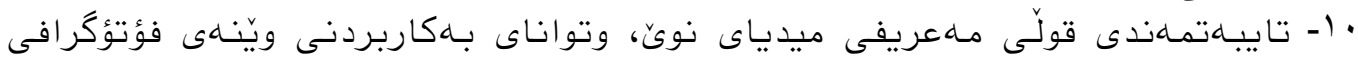

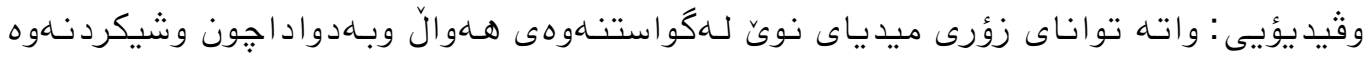

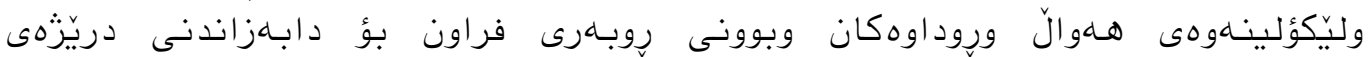

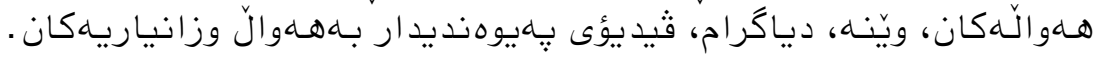

^' - انتصار ابراهيم عبدالرزاق وصفد حسام الساموك، الاعلام الجديد: تطور الاداء و الوسيلة والوظيفة، طا،

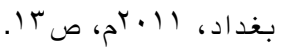

DOI: $10.33193 /$ JALHSS.38.15 


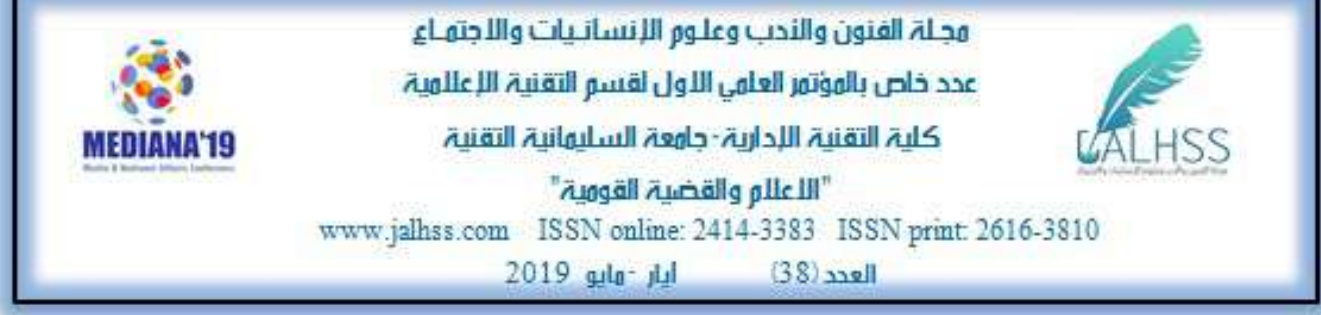

\section{- بـاسى سيّههم: - براكتيكنامهـ -}

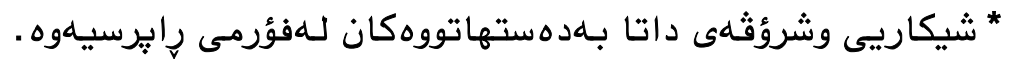

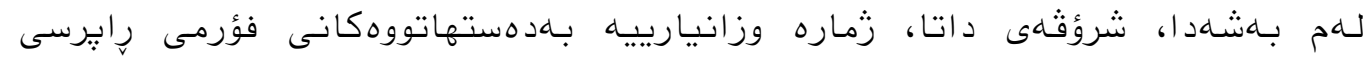

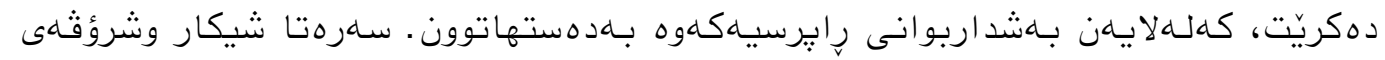

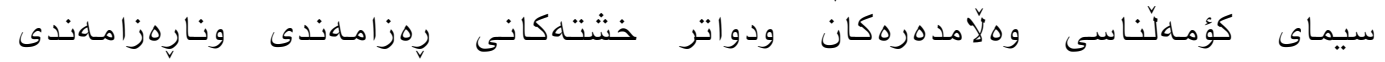

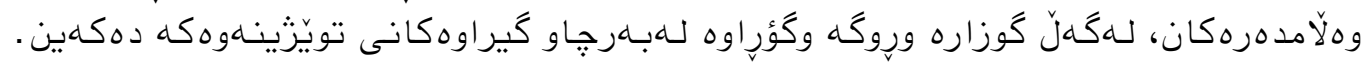

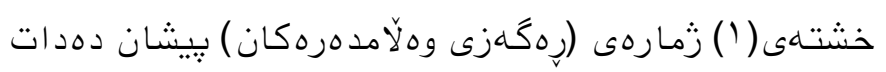

\begin{tabular}{|c|c|c|}
\hline لريّزَهى سهدى & زماره & 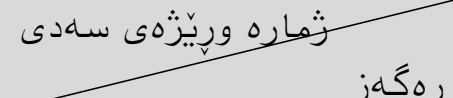 \\
\hline $07, \leqslant \Lambda$ & $1 \% 0$ & نيّر \\
\hline$\varepsilon r, 01$ & $1 \cdot \leq$ & مسئ \\
\hline $1 \ldots$ & rrq & كؤى كُشتى \\
\hline
\end{tabular}

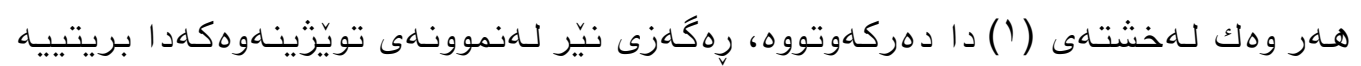

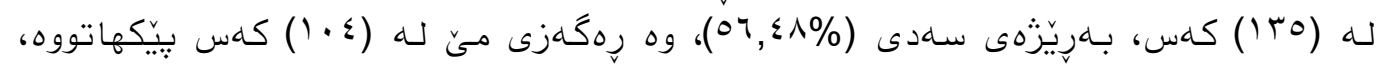

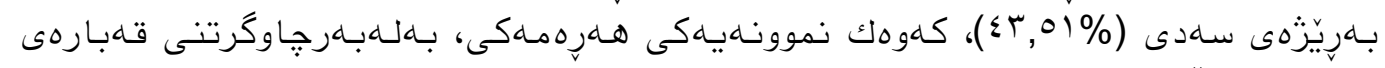

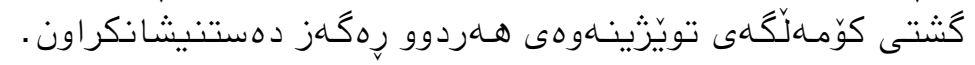

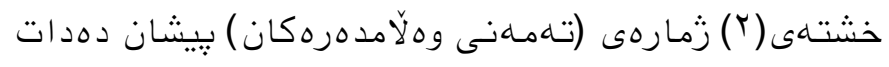

\begin{tabular}{|c|c|c|c|}
\hline رِيَزْهى سهدى & زماره & زمـارهو رِيّزهى سهدى & تـهمـان \\
\hline$V V, \varepsilon$ & 110 & $r r-19$ & .1 \\
\hline $19, Y \leq$ & $\sum 7$ & YA-TE &.$r$ \\
\hline$r, r$ & $\Lambda$ & 1זوزياتر & $r$ \\
\hline $1 \ldots$ & rrq & \multicolumn{2}{|c|}{ كوّى كُشتى } \\
\hline
\end{tabular}

DOI: $10.33193 /$ JALHSS.38.15 


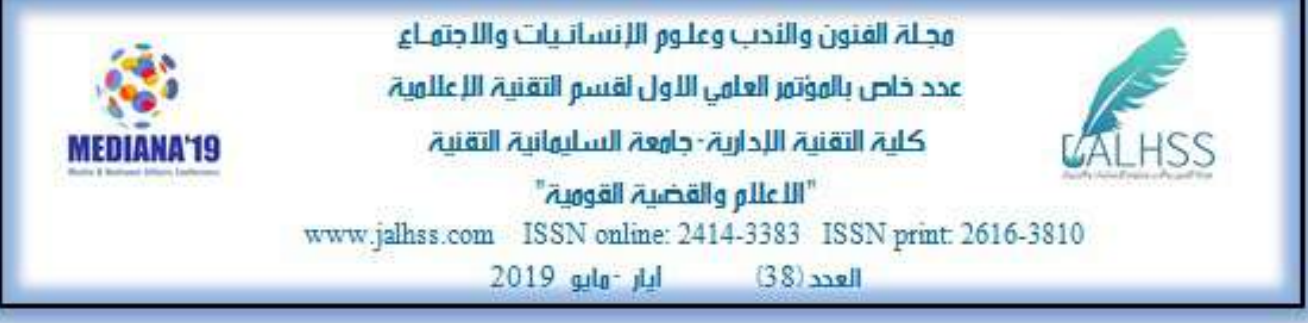

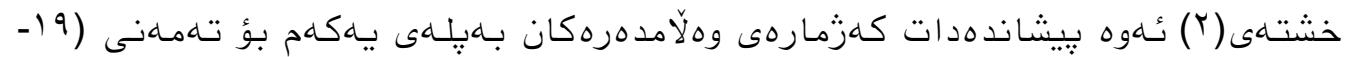

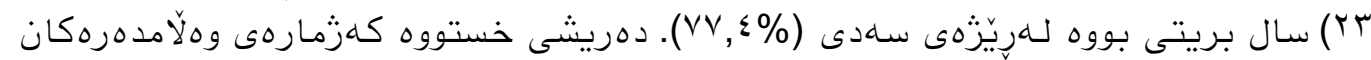

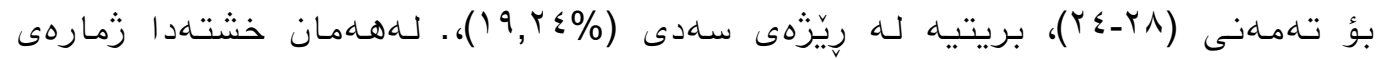

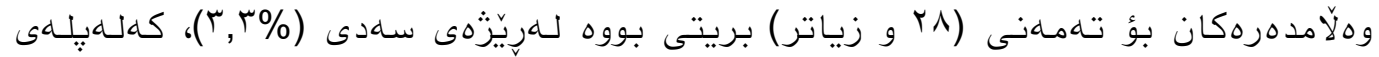

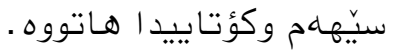

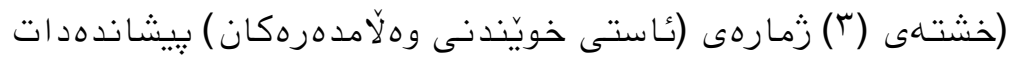

\begin{tabular}{|c|c|c|c|}
\hline ريّزْهى سـدى & زمـاره & \multicolumn{2}{|c|}{ قؤنساغهكانى خويَندن } \\
\hline$r$. & $\sum \Lambda$ & به كهم & .1 \\
\hline$r T, \varepsilon r$ & 07 & دووهم & $r$ \\
\hline $19, Y \leq$ & $\leqslant 7$ & سيِّههم م & $r$ \\
\hline$r V, r T$ & 19 & جوارهم & $\varepsilon$ \\
\hline $1 \ldots$ & rrq & \multicolumn{2}{|c|}{ كؤى كُشتى } \\
\hline
\end{tabular}

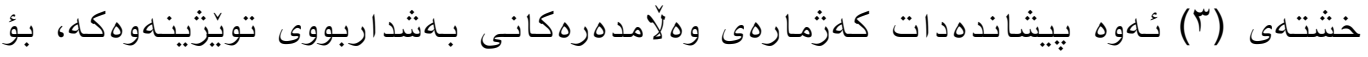

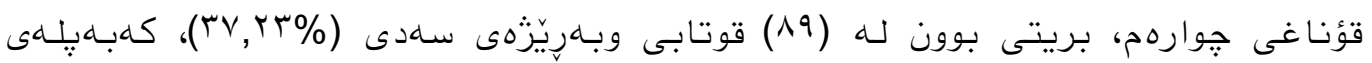

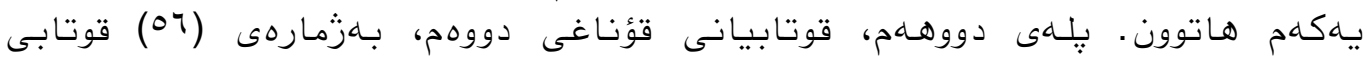

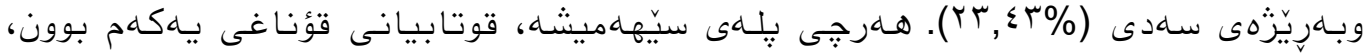

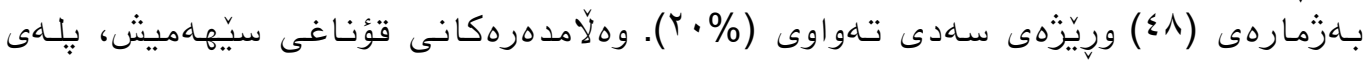

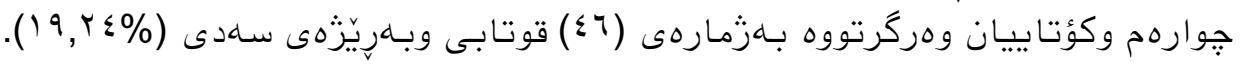

$$
\text { خشتهى (ع) زمارهى (شويّنى وهلامدهرهكان ) بيشيشان دهدات }
$$

\begin{tabular}{|c|c|c|}
\hline رِيْزَهى سهدى & زماره & 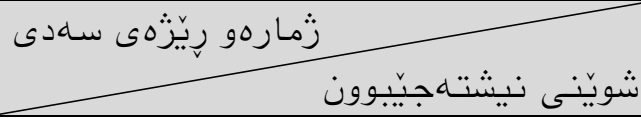 \\
\hline Tr, & 104 & ناوهندى هـهوليَّر \\
\hline 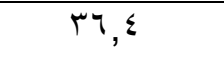 & AV & دهرهوهى هـهوليَّر \\
\hline $1 \cdots$ & rrq & كؤى كُشتى \\
\hline
\end{tabular}

382

DOI: $10.33193 /$ JALHSS.38.15 


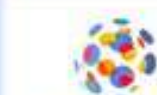

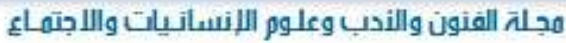 \\ MEDIANA'19

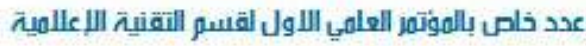 كلية التقنية اللدارية-جامعت السليمانية التقنية " \\ www jalhss.com ISSN online: 2414-3383 ISSN print: $2616-3810$

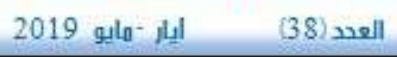

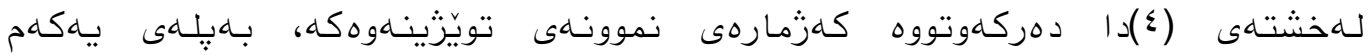

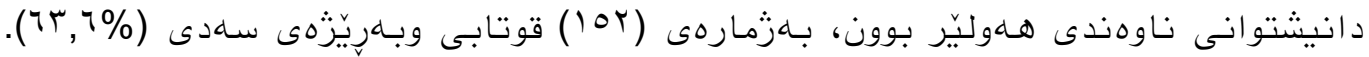

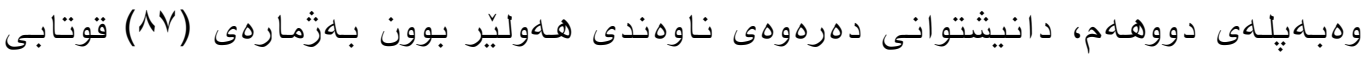

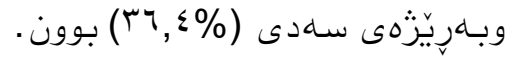

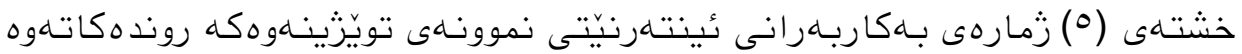

\begin{tabular}{|c|c|c|c|c|}
\hline$\%$ & كؤى كُشتى & رِيَّنهى سـدنى & ز زماره & 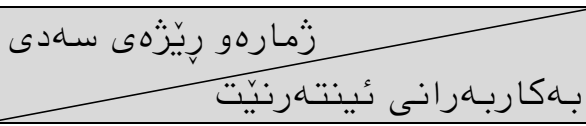 \\
\hline \multirow[t]{2}{*}{$1 \cdots$} & \multirow[t]{2}{*}{ rMq } & 94 & $r r$. & بـالَّلَّ \\
\hline & & $v, q \leq$ & 19 & نـهخير \\
\hline
\end{tabular}

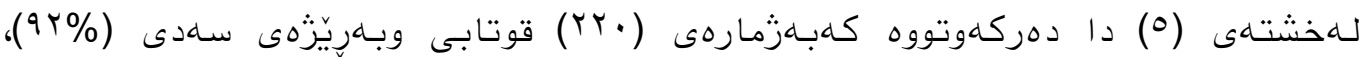

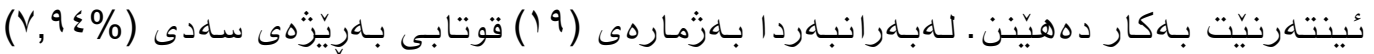

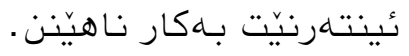

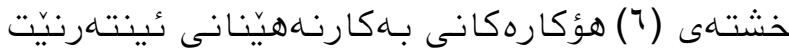

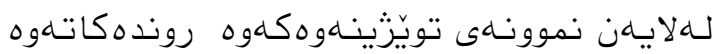

\begin{tabular}{|c|c|c|}
\hline رِيَّنى سهدى & زماره & 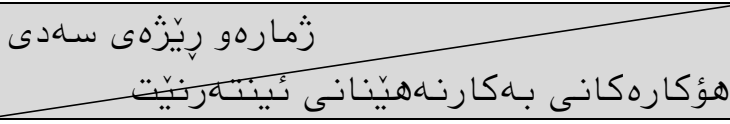 \\
\hline $1 \wedge, 11$ & $\Lambda$ & 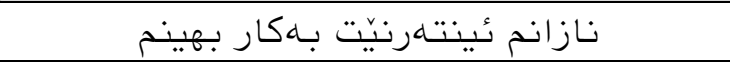 \\
\hline$r \cdot, \leqslant 0$ & 9 & 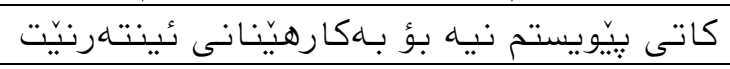 \\
\hline ro & 11 & بشتت بـه كُامرازى ترى رِاكَهياندن دهبهستم \\
\hline 9 & $\varepsilon$ & متمـانهم نيبيه به زانياريهـانى ئينتهرنيّت \\
\hline$r V, r V$ & IT & كرانى و خـاوى نـينتـهـرنِتِ \\
\hline $1 \ldots$ & $\varepsilon \varepsilon$ & كؤى كُشتى \\
\hline
\end{tabular}




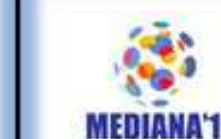

MEDIANA'19

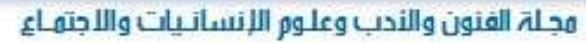

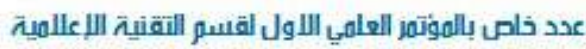
كلية التقنية اللدارية -جامعة السليهانية التقنية

"

www.jalhss.com ISSN online: 2414-3383 ISSN print 2616-3810

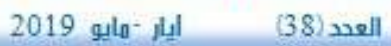

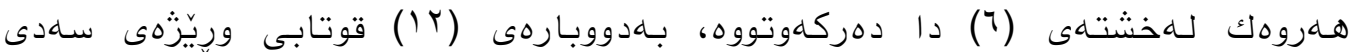

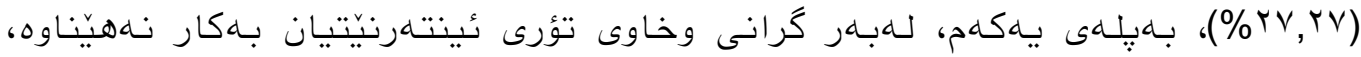

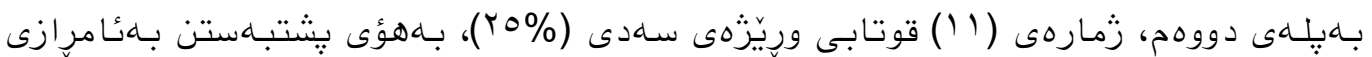

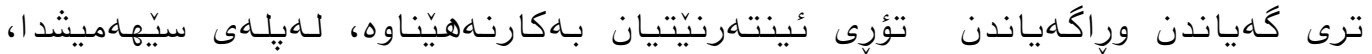

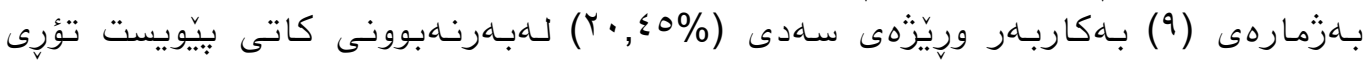

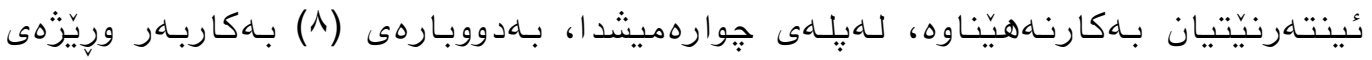

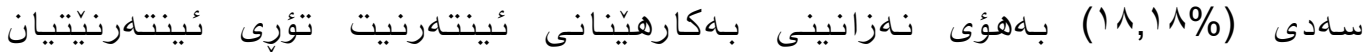

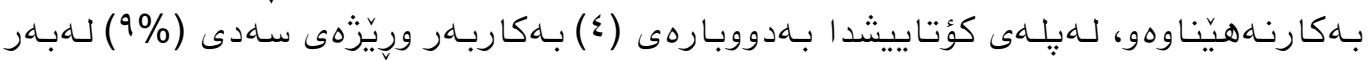

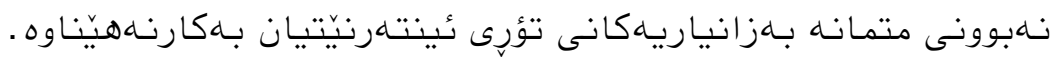

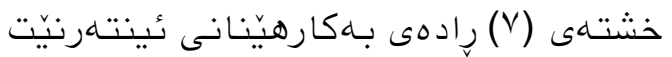

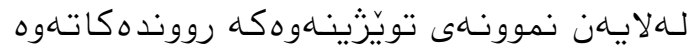

\begin{tabular}{|c|c|c|c|c|c|c|c|c|c|c|}
\hline \multicolumn{2}{|c|}{ يُيْجَِار كهم } & \multicolumn{2}{|c|}{ كهיم } & \multicolumn{2}{|c|}{ مامناوهند } & \multicolumn{2}{|c|}{ زؤر } & \multicolumn{2}{|c|}{ 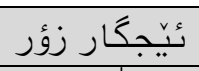 } & \multirow{2}{*}{ كوزاره } \\
\hline$\%$ & $\dot{j}$ & $\%$ & $\dot{j}$ & $\%$ & $\dot{j}$ & $\%$ & $\dot{j}$ & $\%$ & $\dot{j}$ & \\
\hline דr, & $r$ & $r, 11$ & V & $r \wedge, 7 r$ & זד & זד, זים & 111 & 11,11 & rq & 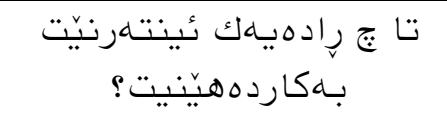 \\
\hline $1 \ldots$ & Tr. & & & & & & & كؤى & & \\
\hline
\end{tabular}

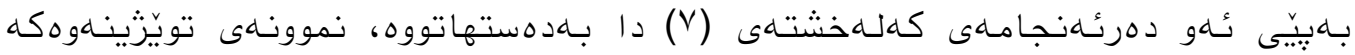

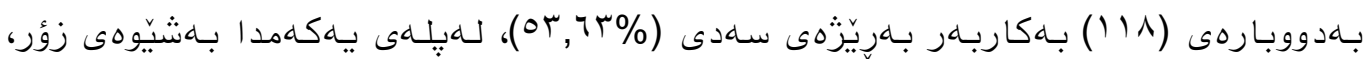

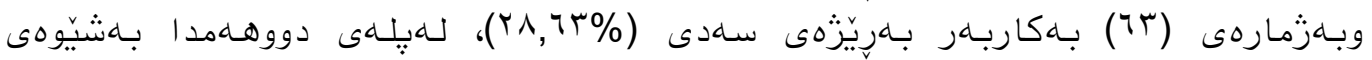

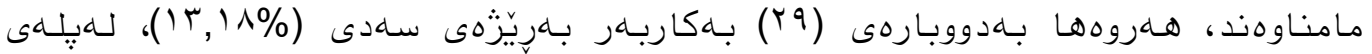

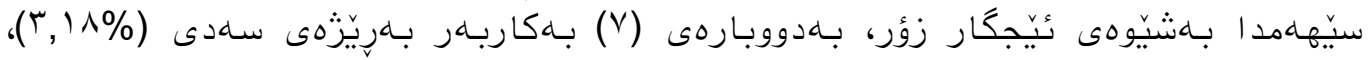

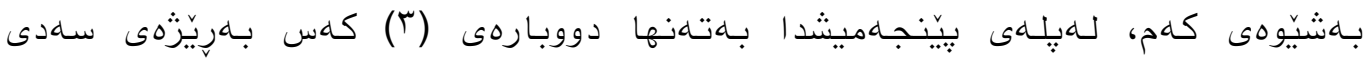

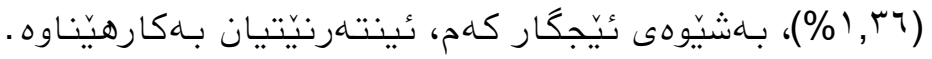

DOI: $10.33193 /$ JALHSS.38.15 


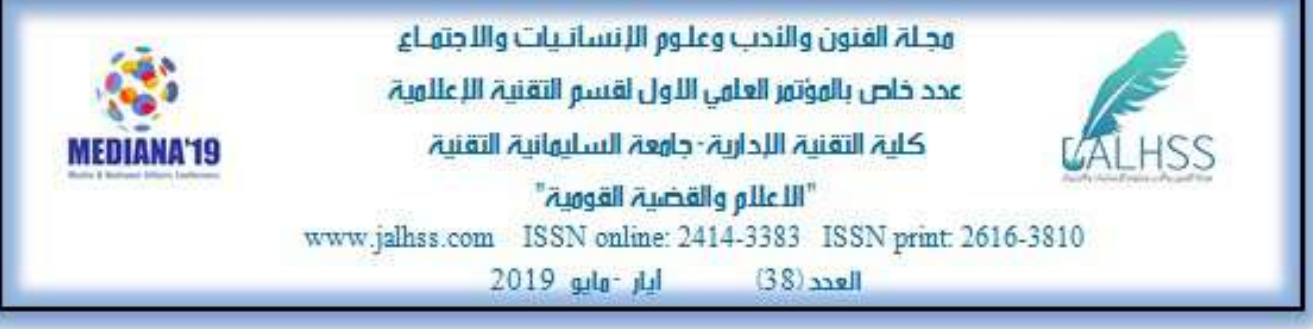

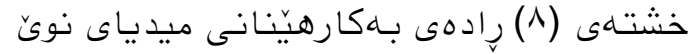

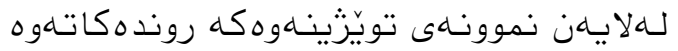

\begin{tabular}{|c|c|c|c|c|c|c|c|c|c|c|}
\hline \multicolumn{2}{|c|}{ يُّيجّار كهم } & \multicolumn{2}{|c|}{ كهم } & \multicolumn{2}{|c|}{ مـامناوهند } & \multicolumn{2}{|c|}{ زؤر } & \multicolumn{2}{|c|}{ يُيْجِار زؤر } & \multirow{2}{*}{ كَوزاره تَهـارهو ريّزَهى سهدى } \\
\hline$\%$ & $\dot{j}$ & $\%$ & $\dot{j}$ & & j & $\%$ & j & $\%$ & j & \\
\hline$Y, Y V$ & 0 & $1 \cdot, \leq 0$ & $r T$ & $Y V, V Y$ & 71 & $\varepsilon V, Y V$ & $1 \cdot \varepsilon$ & $I T, Y V$ & TV & 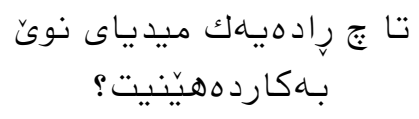 \\
\hline $1 \ldots$ & Yr. & & & & & & & & & \\
\hline
\end{tabular}

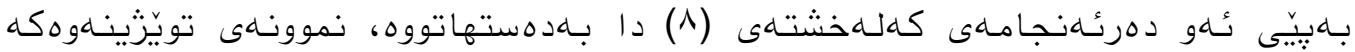

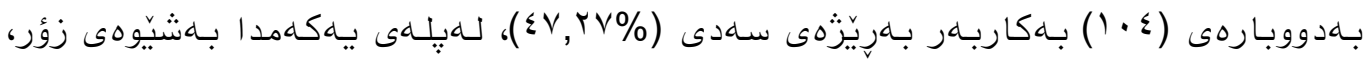

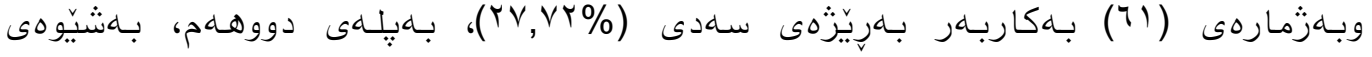

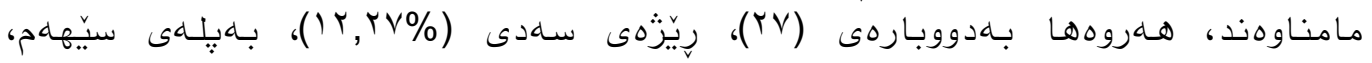

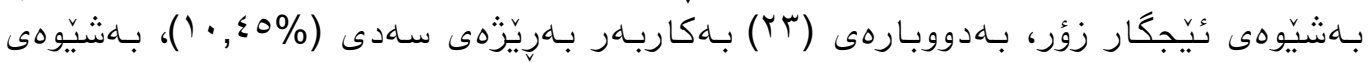

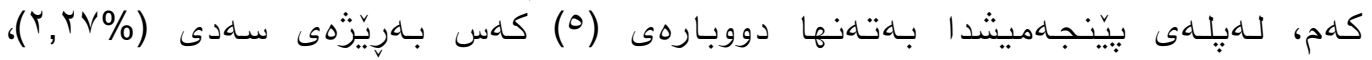

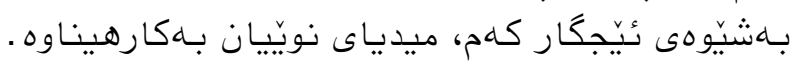




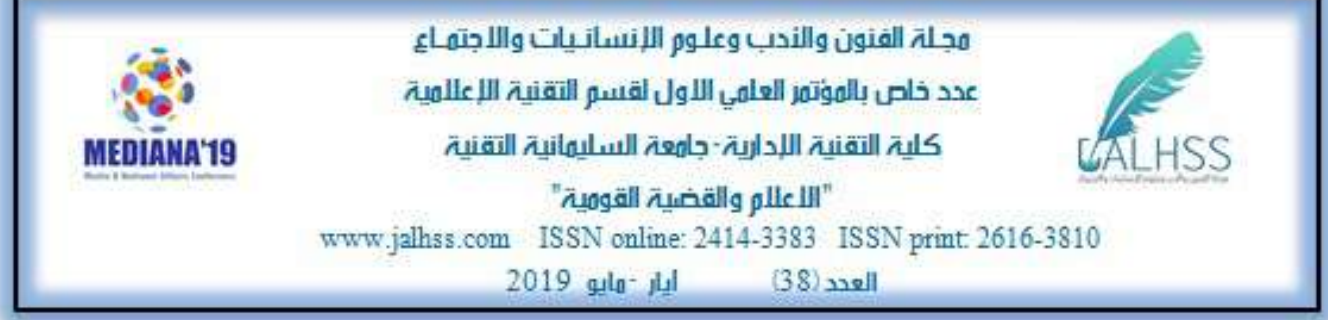

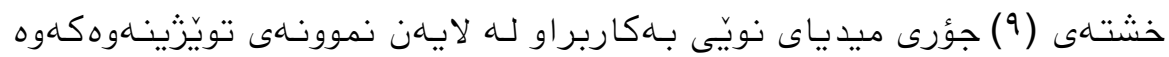

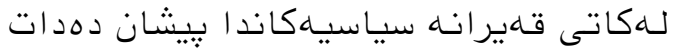

\begin{tabular}{|c|c|c|}
\hline رِيَزْهى سـدنى & | زماره & 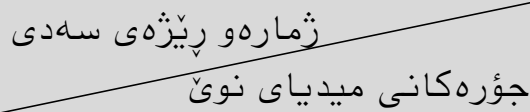 \\
\hline 41,79 & IAr & فـيسبووك \\
\hline$r \cdot, r \Lambda$ & $|V|$ & ئينستاكرام \\
\hline$I V, Y \Lambda$ & $1 \leq 0$ & يوتيوب \\
\hline 11,91 & 11. & تويتهر \\
\hline $1 \cdot, V Y$ & 9 . & مؤبـايل ميديا \\
\hline $1, \varepsilon r$ & Ir & مالبهرهكان \\
\hline$\cdot, \leqslant \vee$ & $\varepsilon$ & وؤتس ئهِب \\
\hline $1 \ldots$ & $\lambda \mu q$ & كؤى گثتى \\
\hline
\end{tabular}

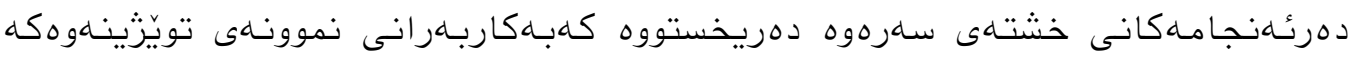

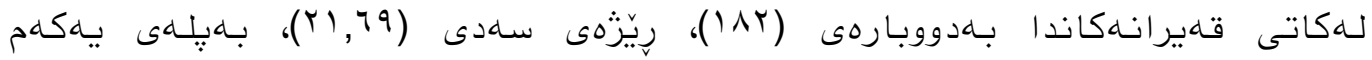

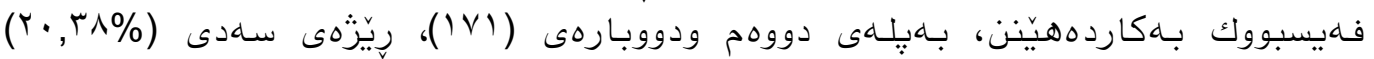

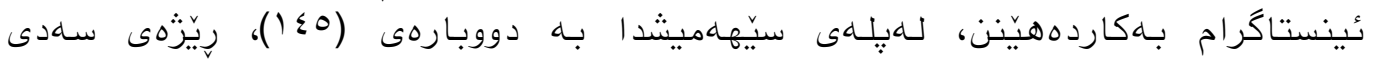

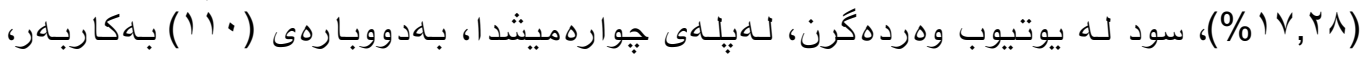

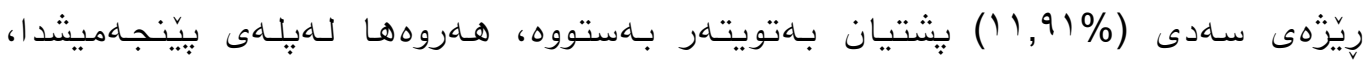

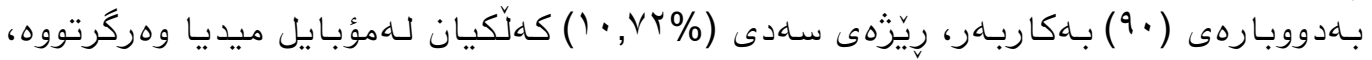

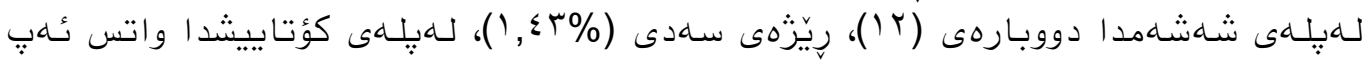

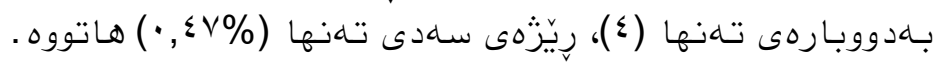




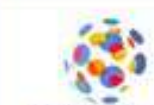 \\ MEDIÄA'19}

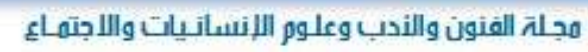

عند خلم بالموتمر العاميا اللاول لقسم التقنية اللاعلاميتر

كلية التقنية الليدازية جامعة السليمانية التقنية

"

www.jalhss.com ISSN online: 2414-3383 ISSN print 2616-3810

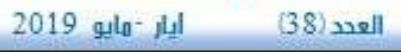

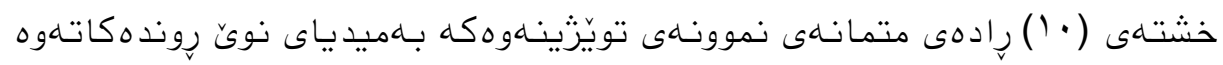

\begin{tabular}{|c|c|c|c|c|c|c|c|c|c|c|}
\hline \multicolumn{2}{|c|}{ يُِّجَِار كهم } & \multicolumn{2}{|c|}{ كهa } & \multicolumn{2}{|c|}{ مـامناوهند } & \multicolumn{2}{|c|}{ زؤر } & \multicolumn{2}{|c|}{ ئيَِِجَار زؤر } & \multirow{2}{*}{ گَوزاره } \\
\hline$\%$ & $\dot{j}$ & $\%$ & $\dot{j}$ & $\%$ & $\dot{j}$ & $\%$ & j & $\%$ & $\dot{j}$ & \\
\hline$\varepsilon$ & 9 & $r \cdot, q$ & $\leqslant 7$ & $\varepsilon \varepsilon$ & $9 V$ & שד, זr & Or & $V, r V$ & 17 & 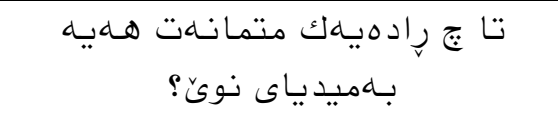 \\
\hline $1 \ldots$ & Tr. & & & & & & & كُشتى & & \\
\hline
\end{tabular}

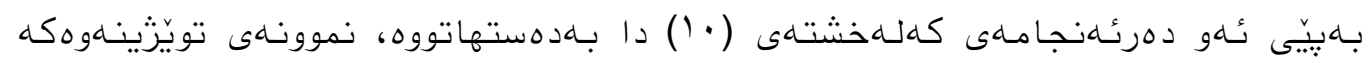

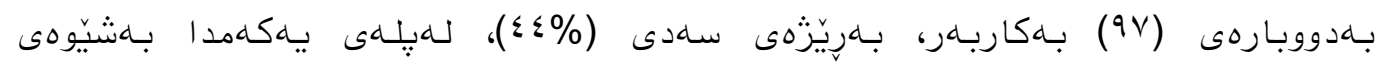

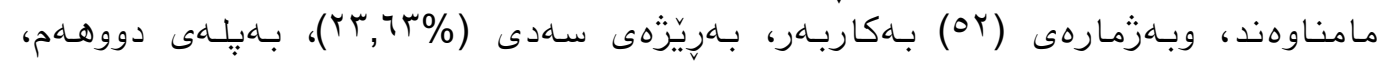

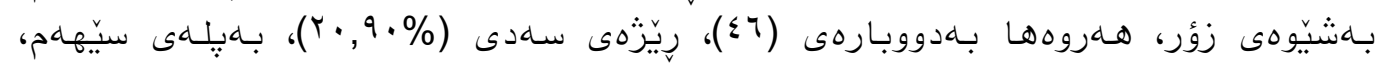

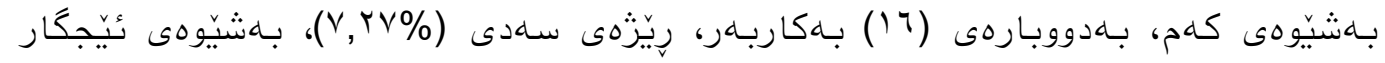

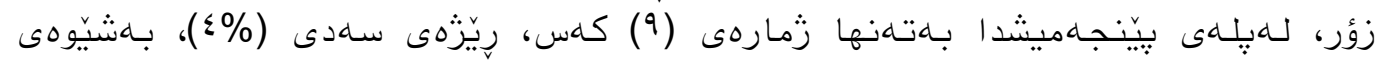

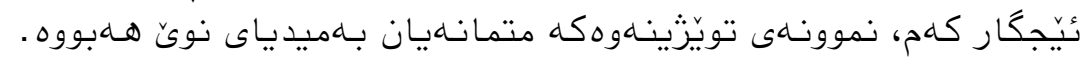

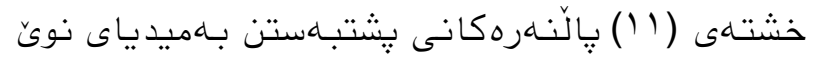

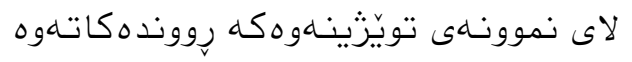

\begin{tabular}{|c|c|c|}
\hline رِيَزْهى سهدى & زماره & رمـارهو رِيَزْهى سهدى \\
\hline$r 1,11$ & $11 \varepsilon$ & فراواني رووبـهرى ئازادى لـه ميديـاى نويّدا . \\
\hline$r 7,90$ & $1 \leqslant 0$ & 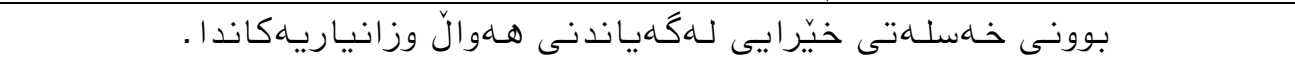 \\
\hline$r_{\cdot}, \leqslant \leqslant$ & 11. & 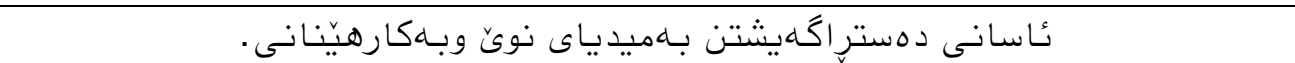 \\
\hline 11,10 & 7. & 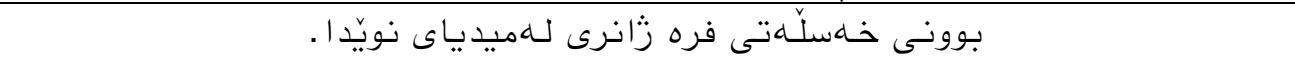 \\
\hline 9,77 & Or & 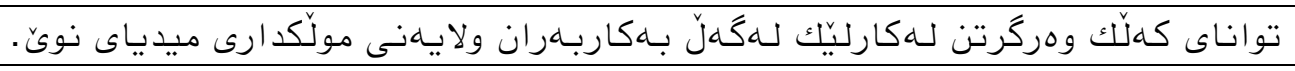 \\
\hline $1 \cdot, 09$ & ov & توانـاى بـهكارهيِنانىى ميدياى نوى لـه هـهموو شويِنيكدا. \\
\hline $1 \cdots$ & ork & كؤى كشتى \\
\hline
\end{tabular}




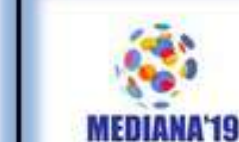

MEDIĀMA'19

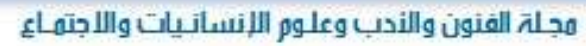

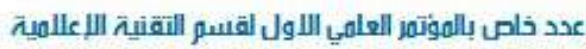

كلية التقنية اللدارية -جامعة السليهانية التقنية

"

www.jalhss.com ISSN online: 2414-3383 ISSN print: 2616-3810

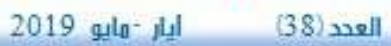

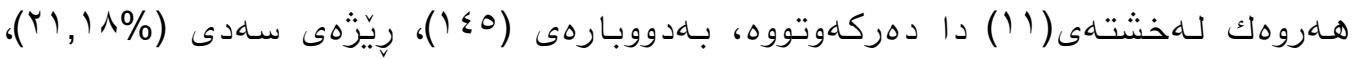

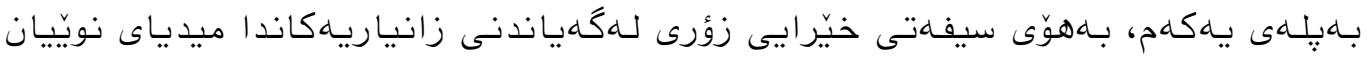

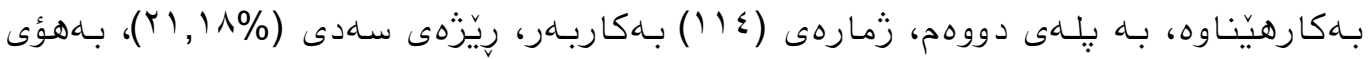

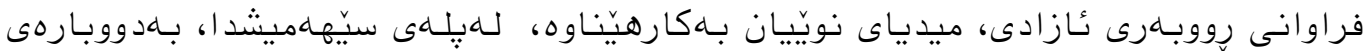

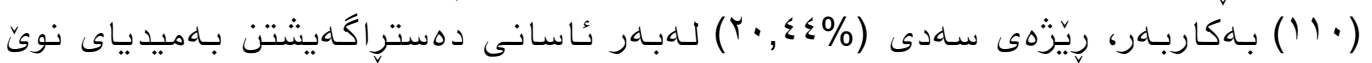

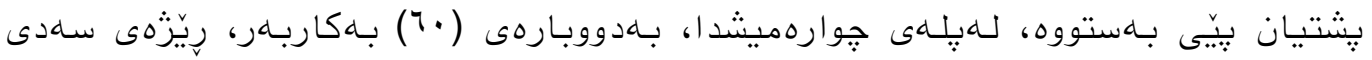

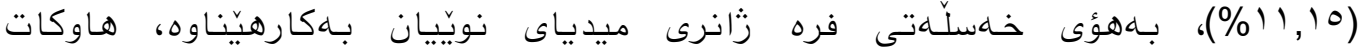

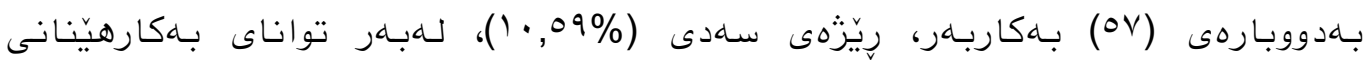

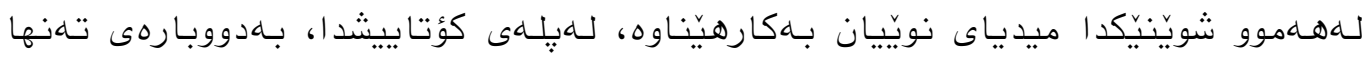

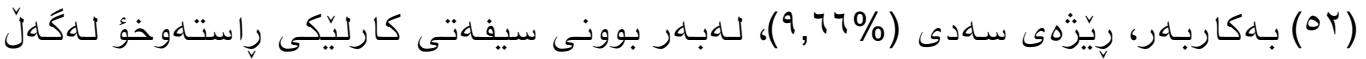

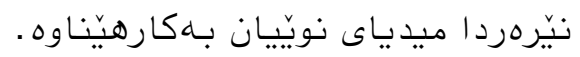

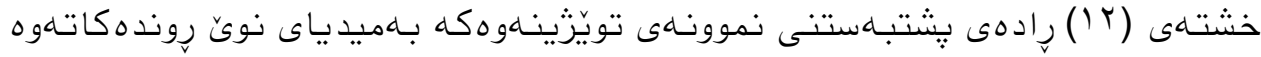

\begin{tabular}{|c|c|c|c|c|c|c|c|c|c|c|}
\hline \multicolumn{2}{|c|}{ يُّيجِكار كهم } & \multicolumn{2}{|c|}{ كهم } & \multicolumn{2}{|c|}{ مـامناوهند } & \multicolumn{2}{|c|}{ زؤر } & \multicolumn{2}{|c|}{ يُيْجِار زؤر } & \multirow{2}{*}{ كوزاره } \\
\hline$\dot{j}$ & $\%$ & $\dot{j}$ & $\%$ & $\dot{j}$ & $\dot{j}$ & $\%$ & j & $\%$ & $\dot{j}$ & \\
\hline$\varepsilon, 0$ & 1. & $\begin{array}{l}r \\
\text {. }\end{array}$ & $\varepsilon \varepsilon$ & M & $v$. & $r o, q$ & $v_{9}$ & $v, V$ & IV & 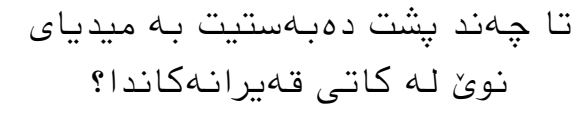 \\
\hline $1 \ldots$ & Tr. & & & & & & & & كؤ & \\
\hline
\end{tabular}

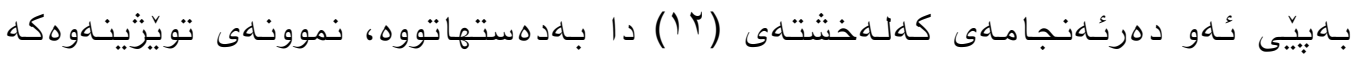

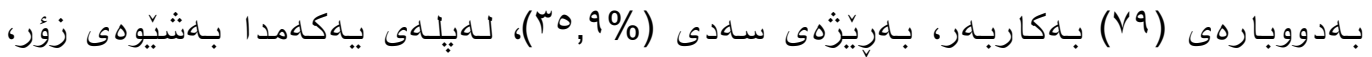

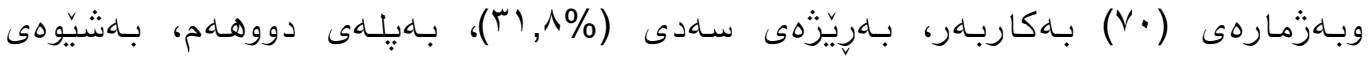

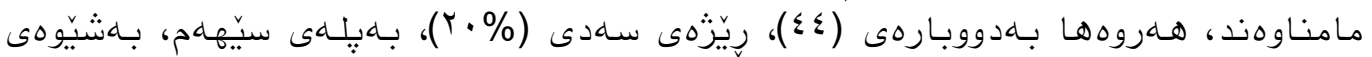

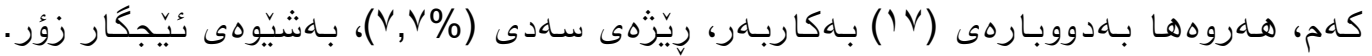

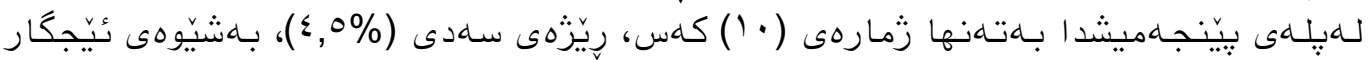

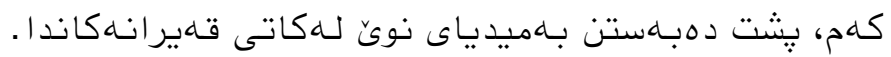

DOI: $10.33193 /$ JALHSS.38.15 


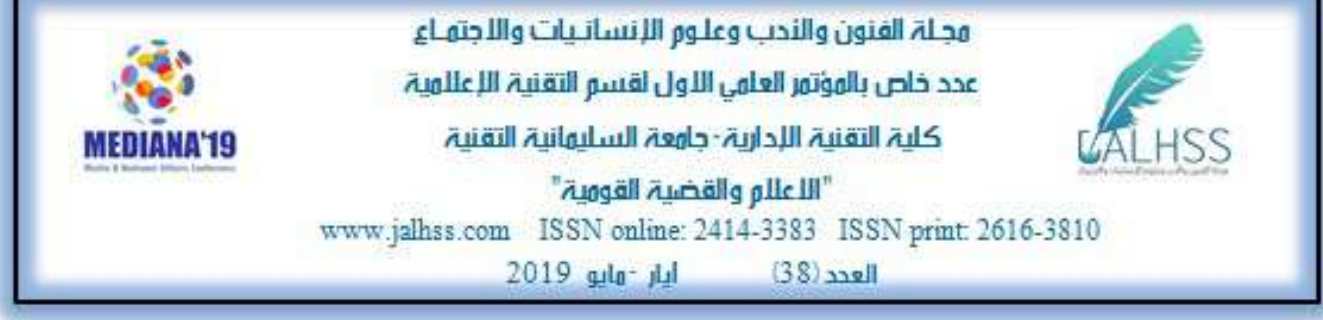

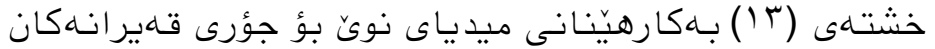

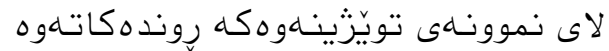

\begin{tabular}{|c|c|c|}
\hline رِيَزْهى سهدى & زماره & جؤرى قهيران \\
\hline$r, v$ & $1 \leqslant r$ & قهيرانى سياسى \\
\hline$r Y, \wedge r$ & $1 . r$ & قـهيرانى ئَابورى \\
\hline $1 \leqslant, \leqslant 1$ & VV & قهيرانى كؤمهلايهـتى \\
\hline$I V, \cdot V$ & 70 & قهيرانى سهربـازى \\
\hline 14,97 & $\pi$ & قهيرانى تهنددروستى \\
\hline $1 \cdots$ & $\leqslant 01$ & كؤى كشتى \\
\hline
\end{tabular}

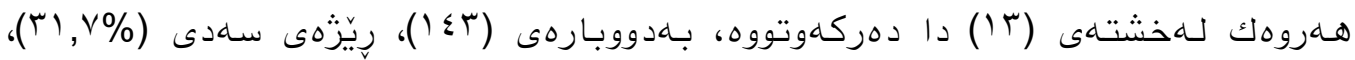

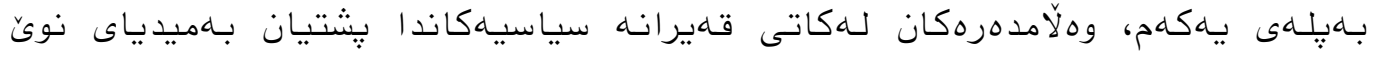

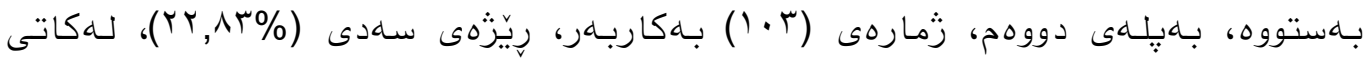

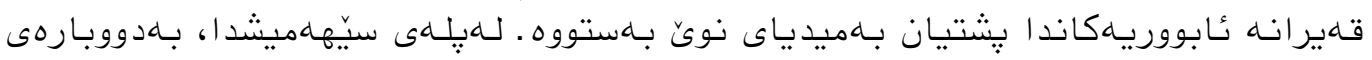
بهاربهار، ريّزّهى سهدى (VV)

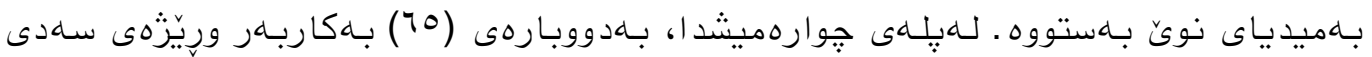

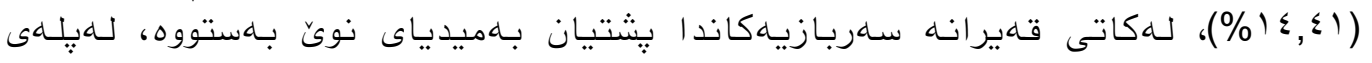

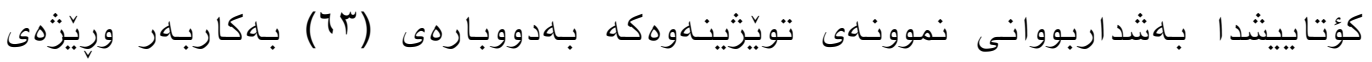

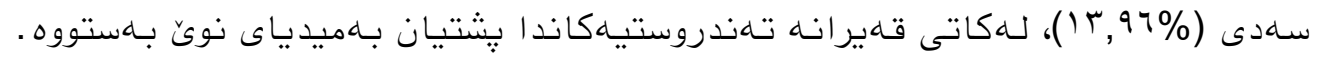

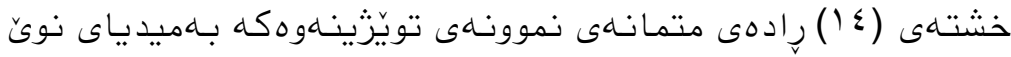

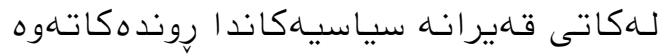

\begin{tabular}{|c|c|c|c|c|c|c|c|c|c|c|}
\hline \multicolumn{2}{|c|}{ تئيِجگَار كهم } & \multicolumn{2}{|c|}{ كهיم } & \multicolumn{2}{|c|}{ مامنـاوهند } & \multicolumn{2}{|c|}{ زؤر } & \multicolumn{2}{|c|}{ نيَِجَِار زؤر } & \multirow{2}{*}{ كَوزاره } \\
\hline$\%$ & $\bar{j}$ & $\%$ & $\dot{j}$ & & $\dot{j}$ & $\%$ & $\dot{j}$ & $\%$ & $\dot{~ j}$ & \\
\hline$V, r V$ & 17 & ra & $\Lambda \pi$ & $r r, T r$ & or & $T \leqslant, \leqslant 0$ & 07 & 0,9 & $1 \pi$ & 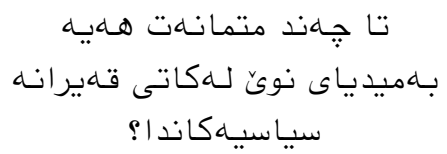 \\
\hline $1 \ldots$ & $r{ }^{\prime}$. & & & & & & & s. & & \\
\hline
\end{tabular}

DOI: $10.33193 /$ JALHSS.38.15 


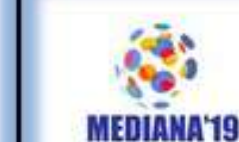

MEDIANA'19

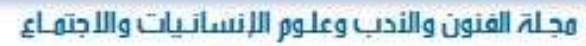

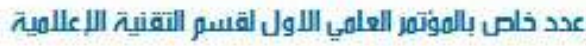

كلية التقنية اللدارية -جامعة السليهانية التقنية

"

www.jalhss.com ISSN online: 2414-3383 ISSN print: 2616-3810

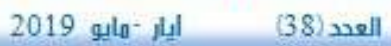

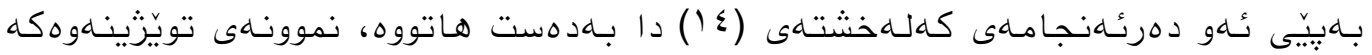

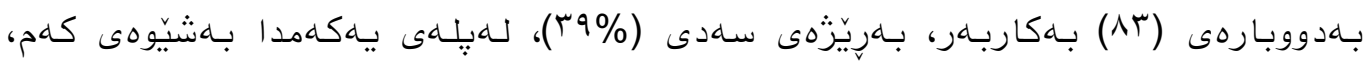

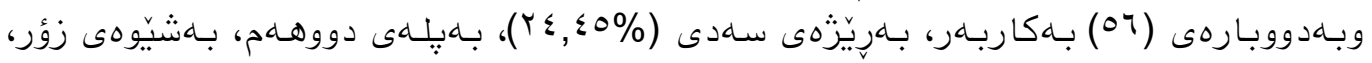

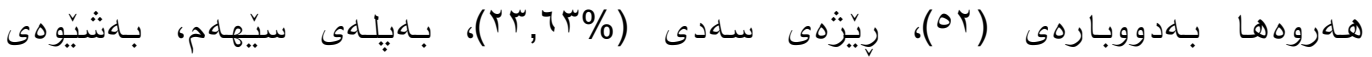

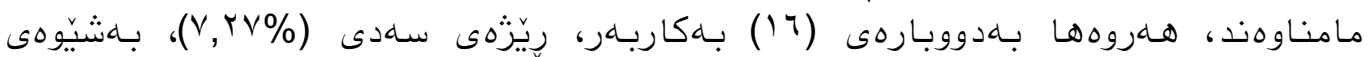

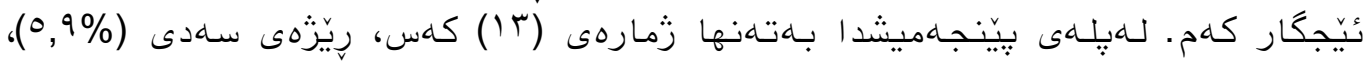

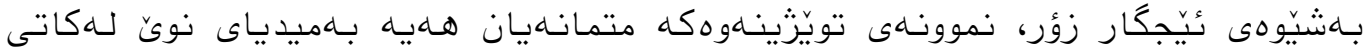

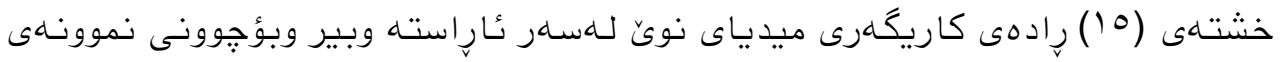

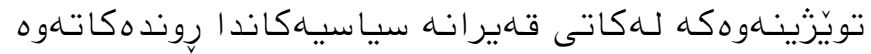

\begin{tabular}{|c|c|c|c|c|c|c|c|c|c|c|}
\hline \multicolumn{2}{|c|}{ يُِّجِحًار كهم } & \multicolumn{2}{|c|}{ كهa } & \multicolumn{2}{|c|}{ مامناوهند } & \multicolumn{2}{|c|}{ زؤر } & \multicolumn{2}{|c|}{ تـيِجِحَار زؤر } & \multirow{2}{*}{ كَوزاره رَمارو ريَرَّهى سهدى } \\
\hline$\%$ & $\dot{j}$ & $\%$ & j & $\%$ & $\dot{j}$ & $\%$ & $\dot{j}$ & $\%$ & $\dot{j}$ & \\
\hline$V, Y V$ & 17 & $r 7, \wedge 1$ & (1) & $Y Y, V Y$ & 0. & $Y V, V T$ & 71 & $0, \leqslant 0$ & Ir & 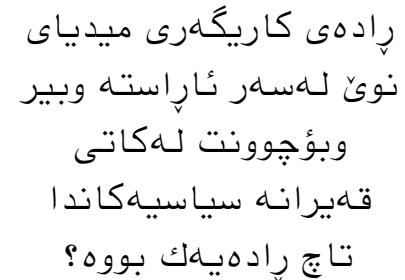 \\
\hline $1 \ldots$ & $r r$. & & & & & & & & & \\
\hline
\end{tabular}

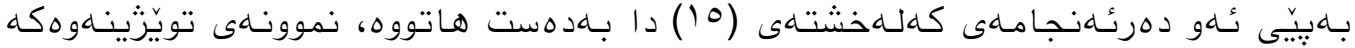

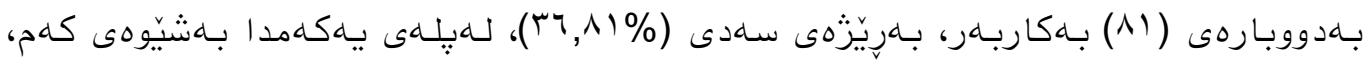

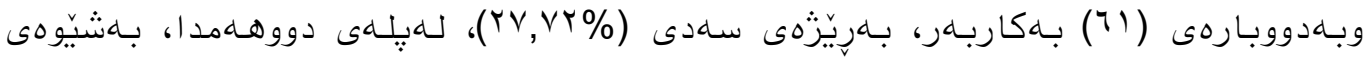

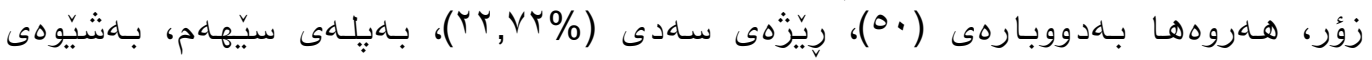

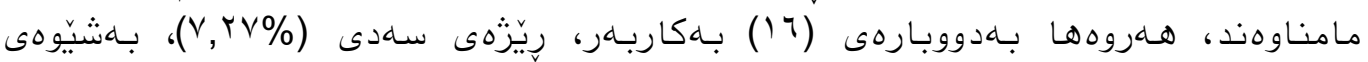

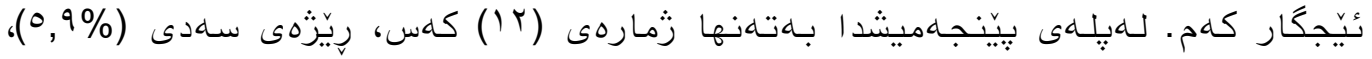

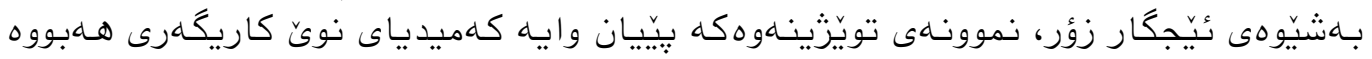

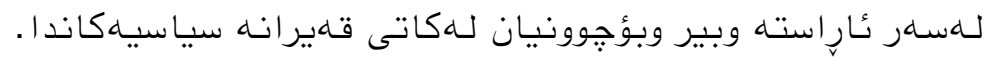

DOI: $10.33193 /$ JALHSS.38.15 


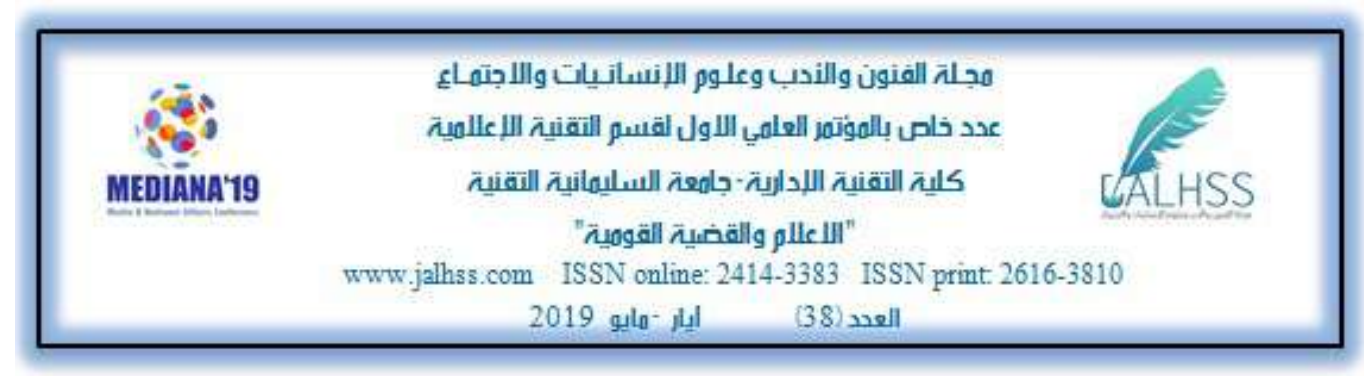

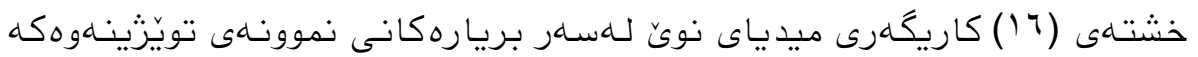

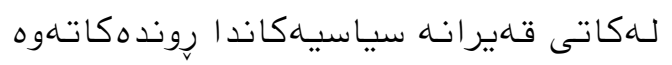

\begin{tabular}{|c|c|c|c|c|c|c|c|c|c|c|}
\hline \multicolumn{2}{|c|}{ يُّيْجَار كهم } & \multicolumn{2}{|c|}{ كلهم } & \multicolumn{2}{|c|}{ مـامنـاوهند } & \multicolumn{2}{|c|}{ زؤر } & \multicolumn{2}{|c|}{ تيُيْجَار زؤر } & \multirow{2}{*}{ كوزاره } \\
\hline$\%$ & j & $\%$ & j & $\%$ & $\dot{j}$ & $\%$ & j & $\%$ & j & \\
\hline 1, $7 \pi$ & 19 & $\Gamma, 11$ & v. & rr, & 01 & $Y V, Y V$ & 7. & 9 & $r$. & 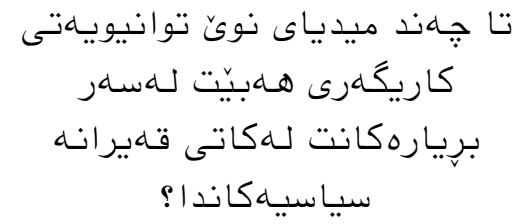 \\
\hline $1 \ldots$ & TY. & & & & & & & ى & & \\
\hline
\end{tabular}

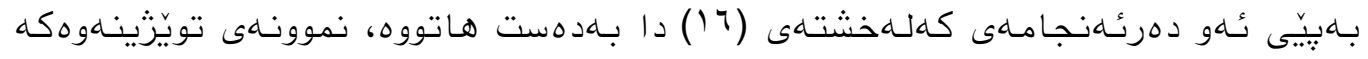

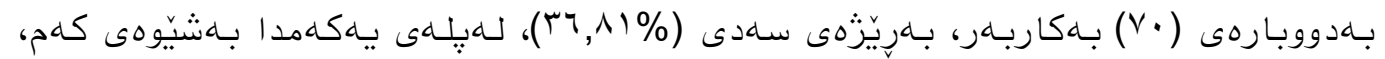

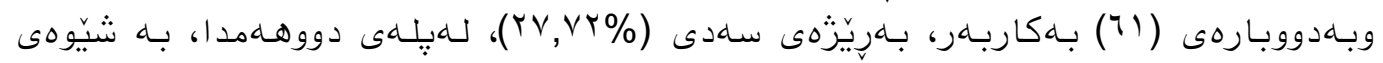

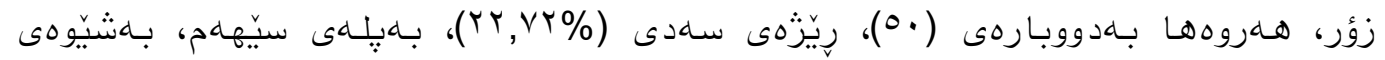

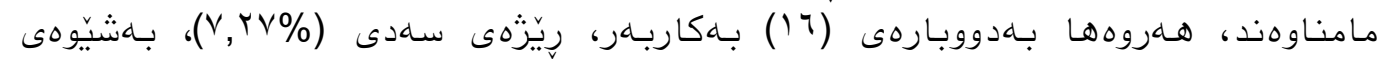

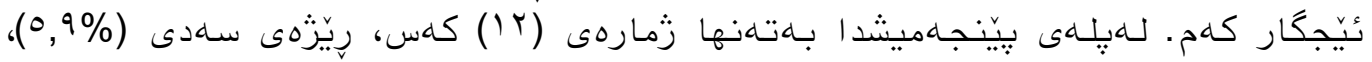

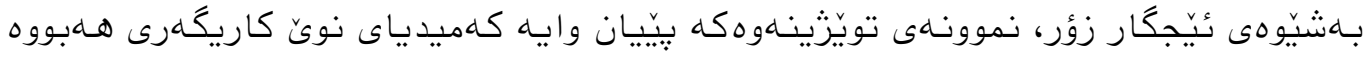

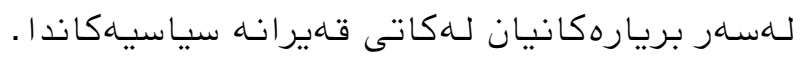

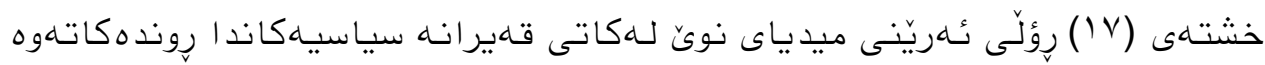

\begin{tabular}{|c|c|c|c|c|c|c|c|c|c|c|}
\hline \multicolumn{2}{|c|}{ نيِّجِار كهم } & \multicolumn{2}{|c|}{ كهיم } & \multicolumn{2}{|c|}{ مـامنـاوهند } & \multicolumn{2}{|c|}{ زؤر } & \multicolumn{2}{|c|}{ تئيِجكَار زؤر } & \multirow{2}{*}{ كوزاره } \\
\hline$\%$ & ز & $\%$ & $\dot{j}$ & $\%$ & j & $\%$ & j & $\%$ & $\dot{j}$ & \\
\hline $1 \cdot, 9$ & $r \varepsilon$ & $7 \cdot, 9$ & $1 \pi \varepsilon$ & 17,1 & rv & $7, \wedge$ & 10 & $\varepsilon, 0$ & 1. & 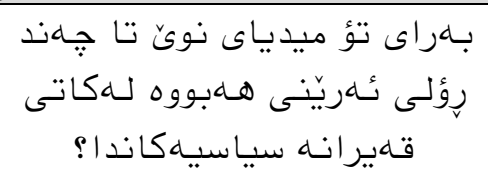 \\
\hline $1 \ldots$ & Yr. & & & & & & & كَث: & & \\
\hline
\end{tabular}

DOI: $10.33193 /$ JALHSS.38.15 


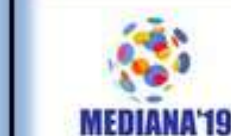

MEDIĀMA'19
هجلة الفنون والندب وعلوم اللانسانيات واللاجتهاء

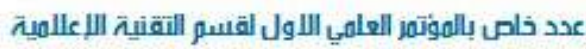

كلية التقنية اللدارية - جامعة السليمانية التقنية

"

www.jalhss.com ISSN online: 2414-3383 ISSN print 2616-3810

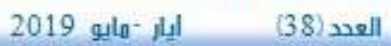

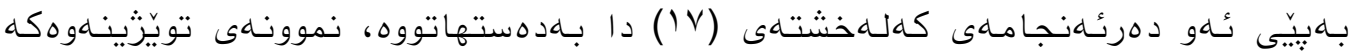

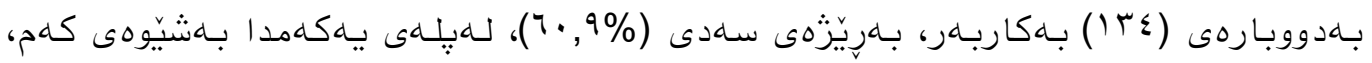

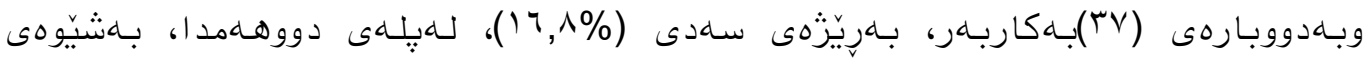

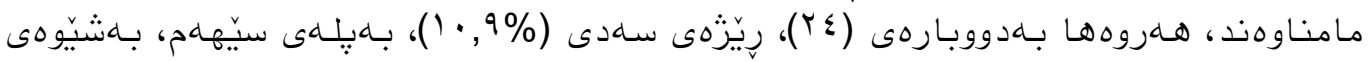

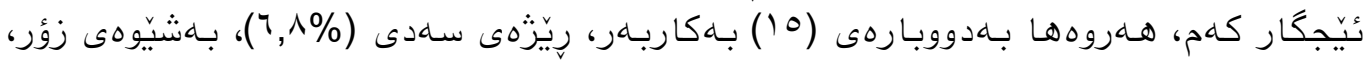

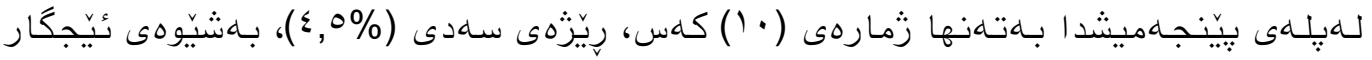

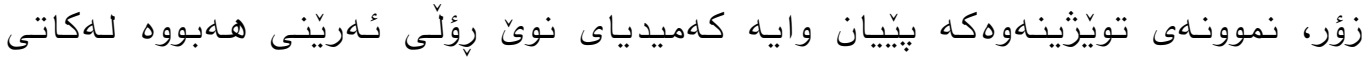

قهير انه سياسيهكاند ا.

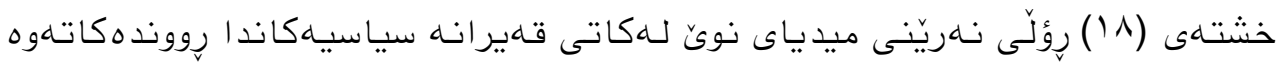

\begin{tabular}{|c|c|c|c|c|c|c|c|c|c|c|}
\hline \multicolumn{2}{|c|}{ ئيّجَِار كهم } & \multicolumn{2}{|c|}{ كهم } & \multicolumn{2}{|c|}{ مـامناوهند } & \multicolumn{2}{|c|}{ زؤر } & \multicolumn{2}{|c|}{ يُيْجَِار زؤر } & \multirow{2}{*}{ كوزاره } \\
\hline$\%$ & $\dot{j}$ & $\%$ & $\dot{j}$ & $\%$ & $\dot{j}$ & $\%$ & j & $\%$ & $\dot{j}$ & \\
\hline r, & $\wedge$ & 1. & $r Y$ & $19,0 \leqslant$ & $\varepsilon r$ & క1, & 91 & $r_{0}, \leq 0$ & 07 & 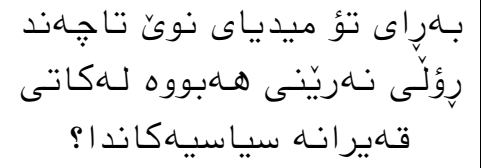 \\
\hline
\end{tabular}

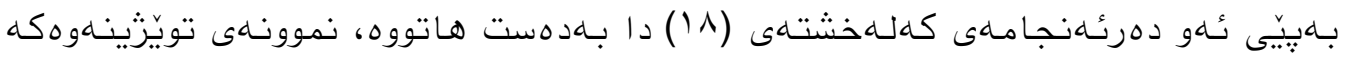

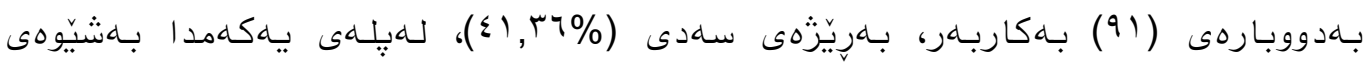

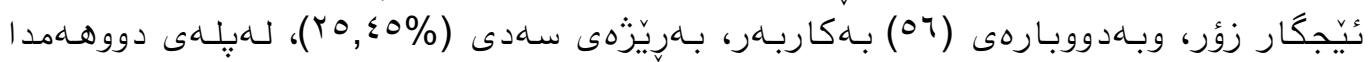

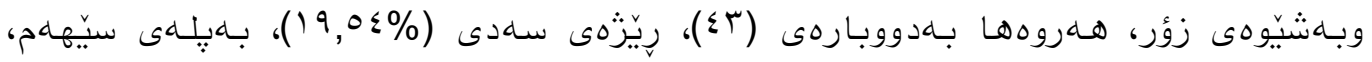

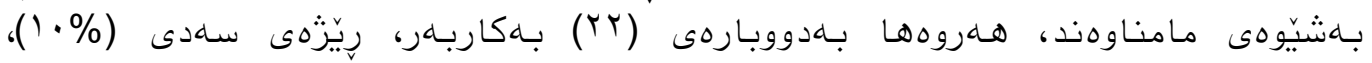

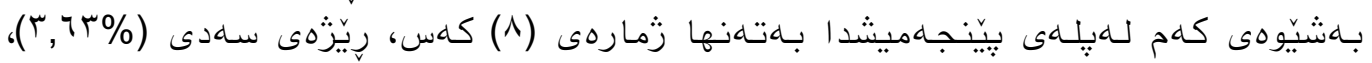

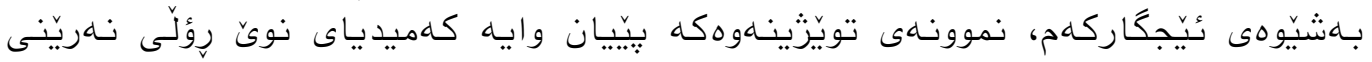

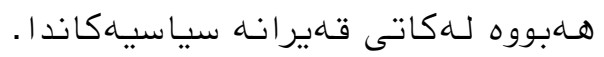




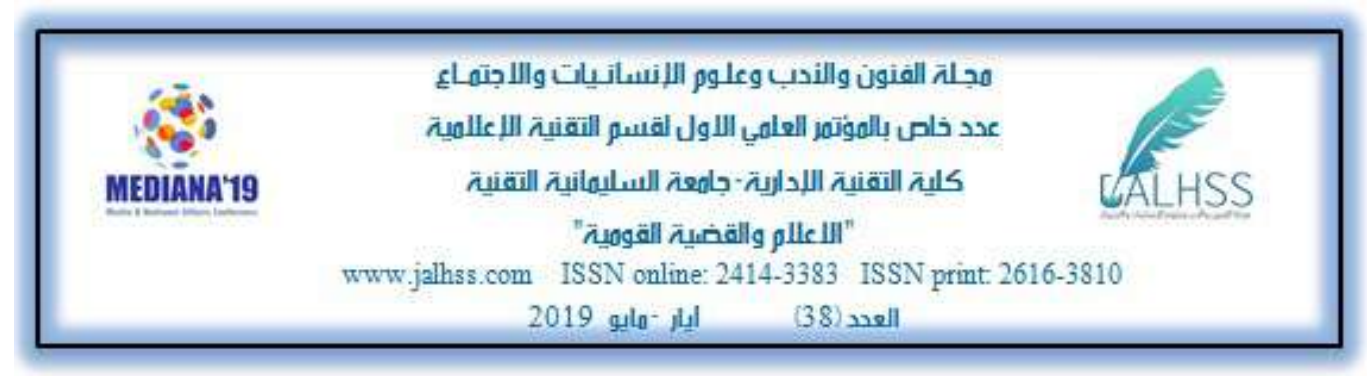

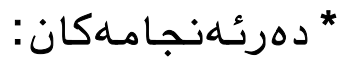

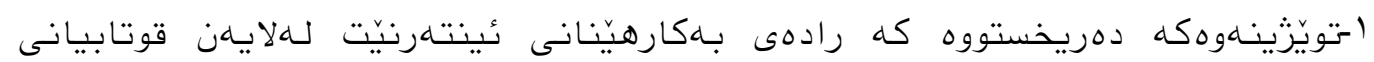

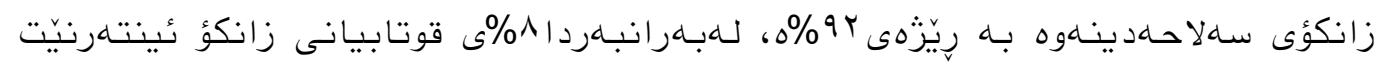

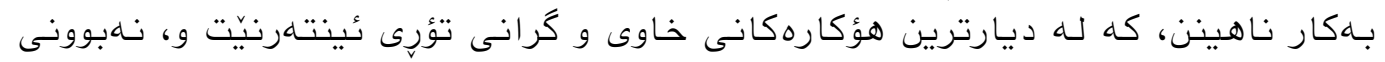

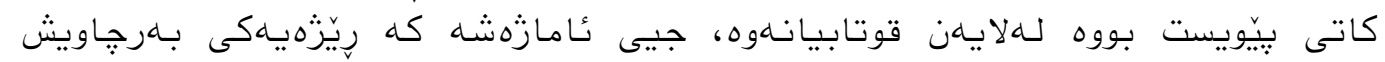

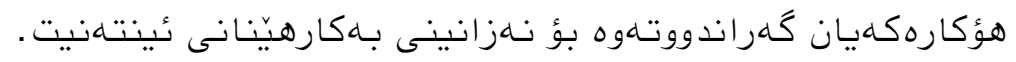

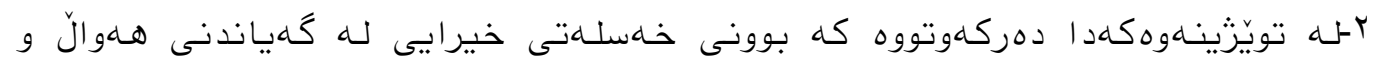

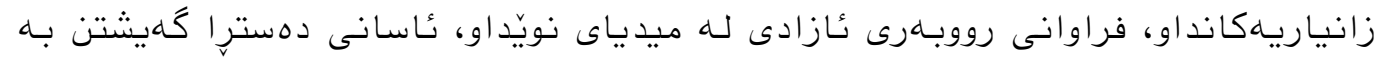

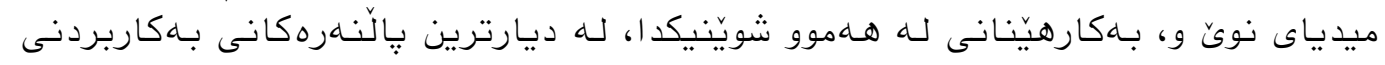

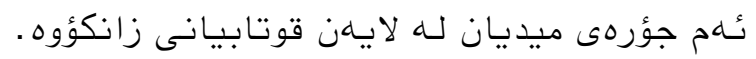

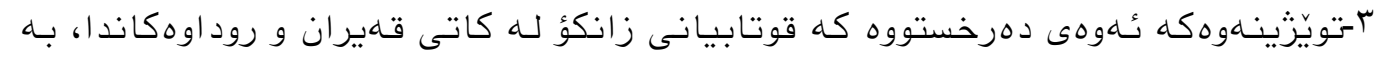

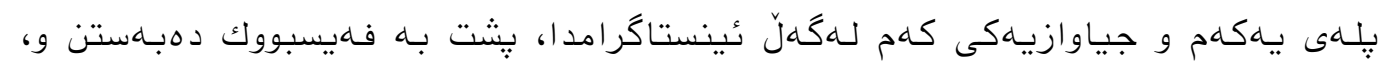

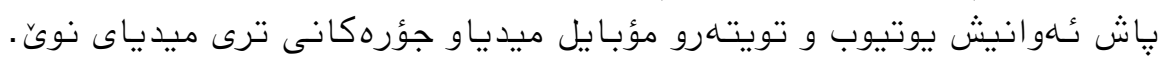

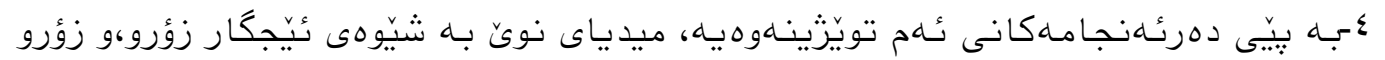

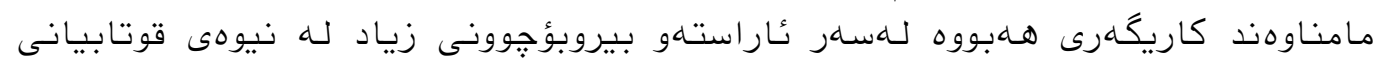

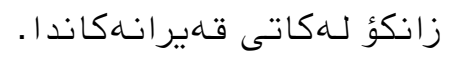

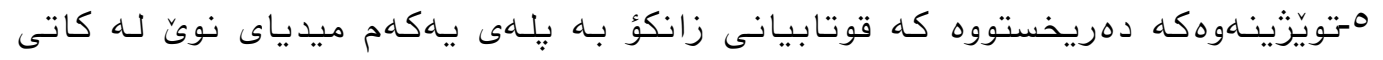

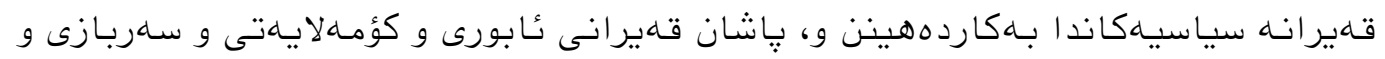

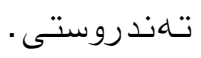

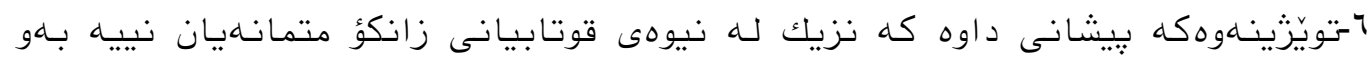

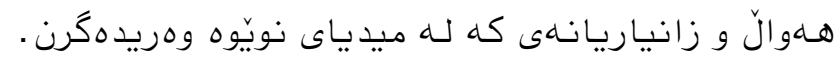

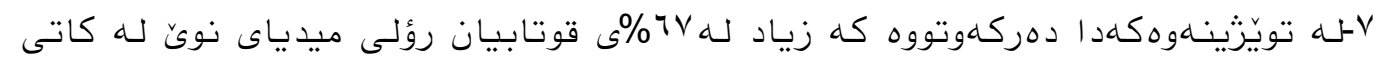

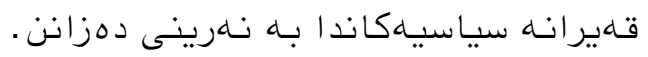

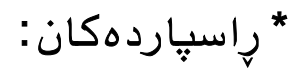

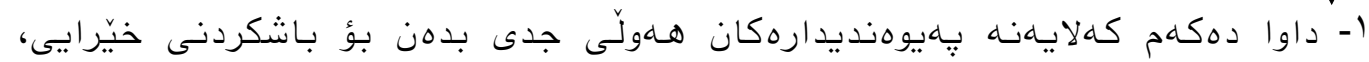

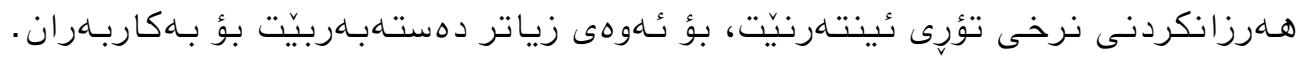

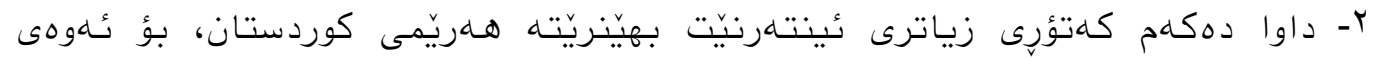

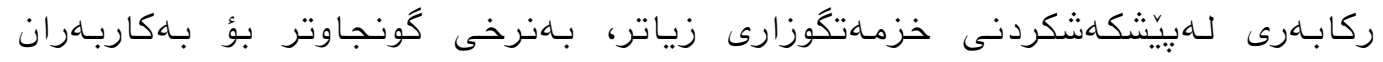
ده ستهبهابريخيت. 


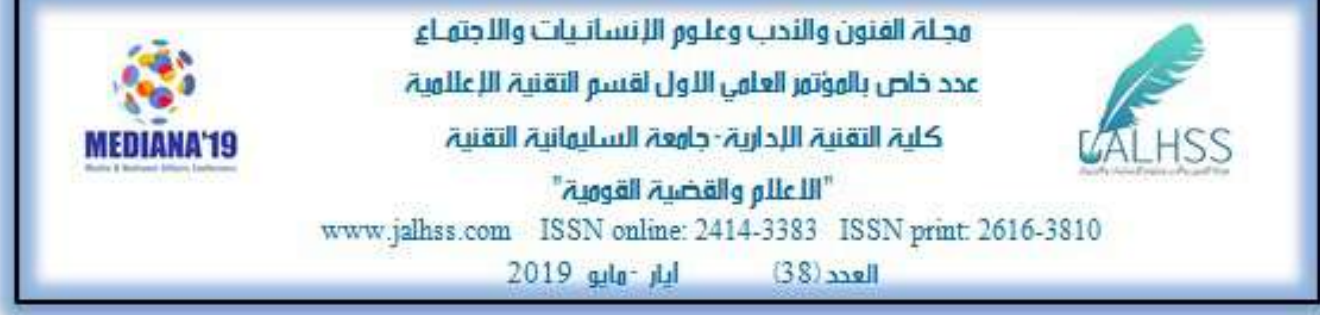

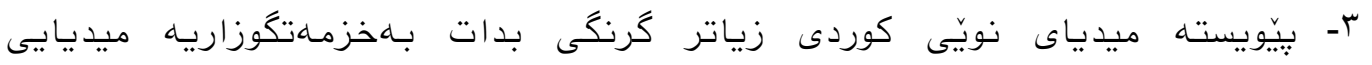

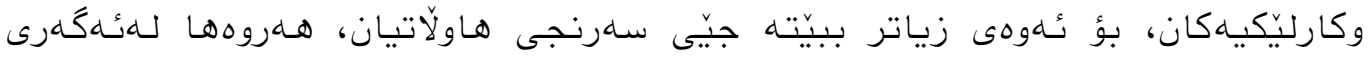

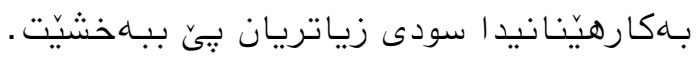

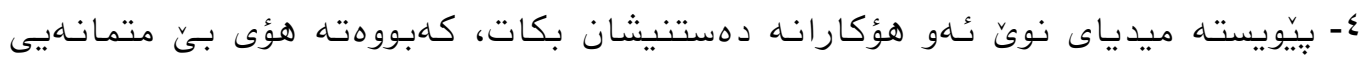

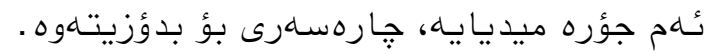

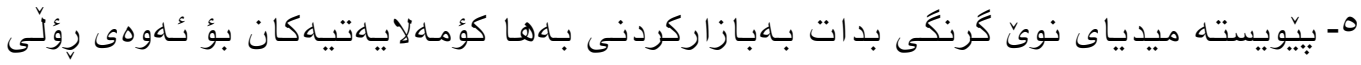

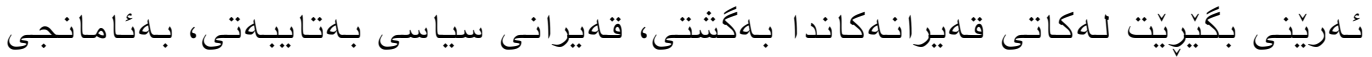
جارهسهركردنيان.

$$
\text { - سهرجياوهكان: }
$$

ا- ابراهيم ابو عرقوب، الاتصال الانسانى ودوره في التفاعل الاجتماعى، طك، دار مجدلاوى

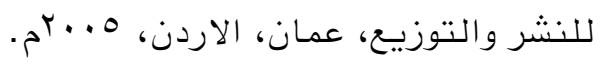
r- انتصار ابراهيم عبدالرزاق وصفد حسام الاردن، الساموك، الاعلام الجديد: تطور الاداء

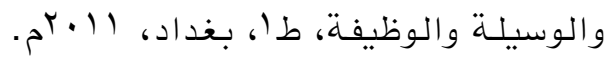

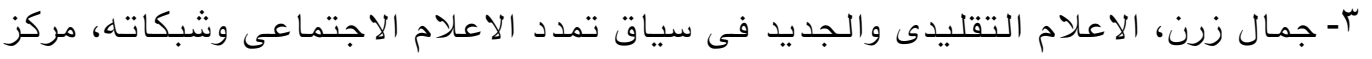

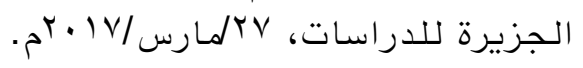

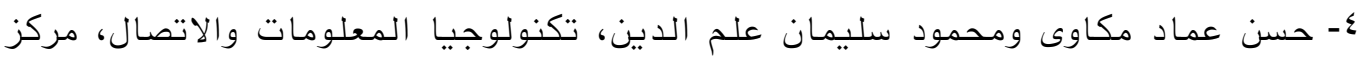

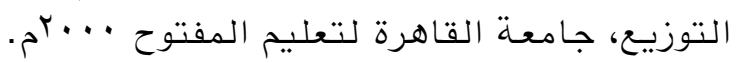

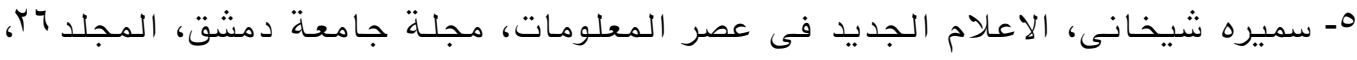

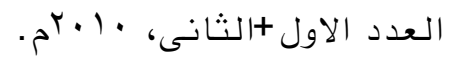

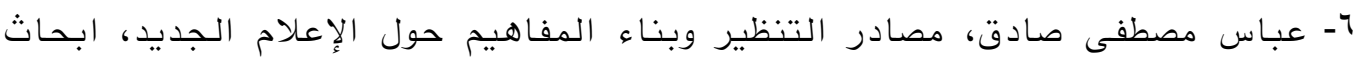

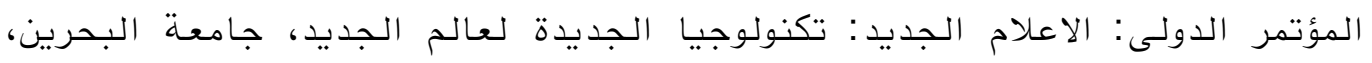

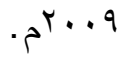

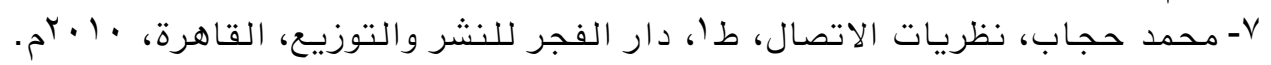

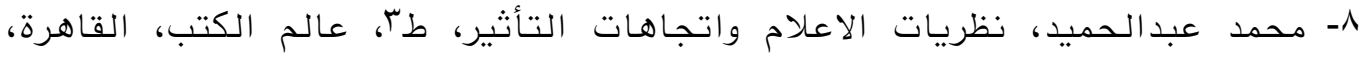

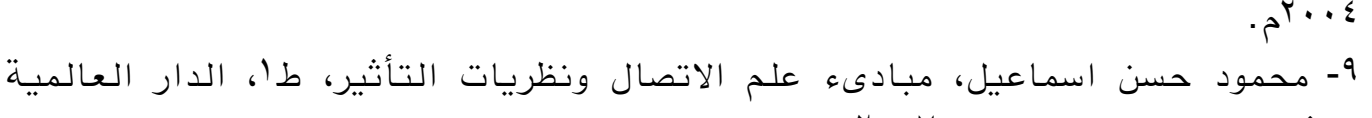

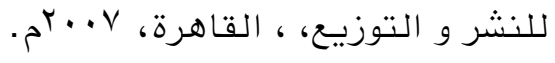

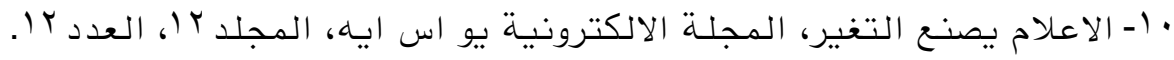




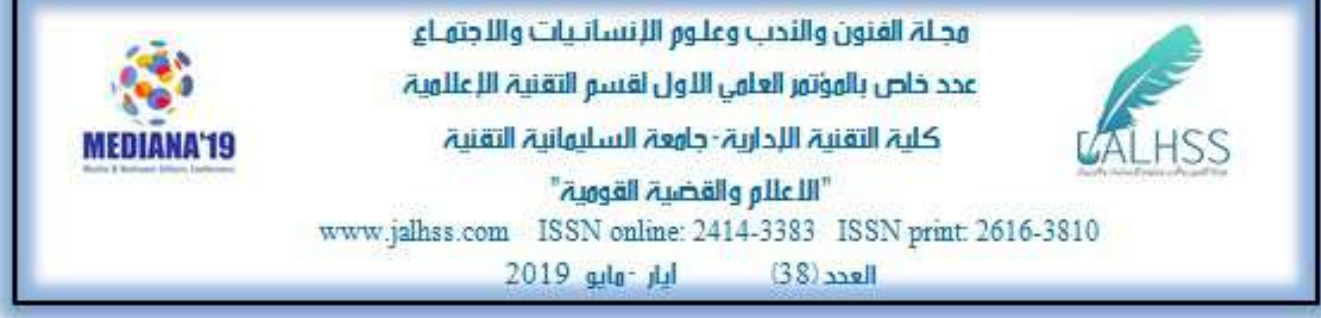

لا إ- محمود عبدالسلام على، الحملات الاعلامية، طا، دار المعتز للنشر والتوزيع، اردن،

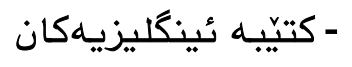

1- Dan Gilmor، We The Media، 2003.

r. Linda Weiser Friedman ، Hershey H. Friedman ، THE NEW MEDIA TECHNOLOGIES: OVERVIEW AND RESEARCH FRAMEWORK، Baruch College and the Graduate Center of the City University of New York، April 2008.

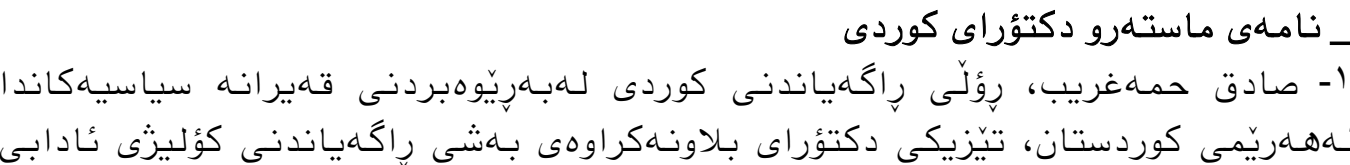

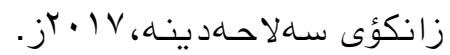

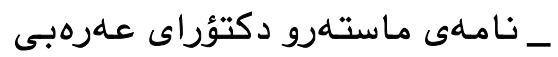

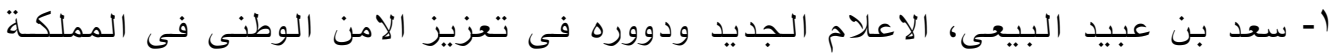

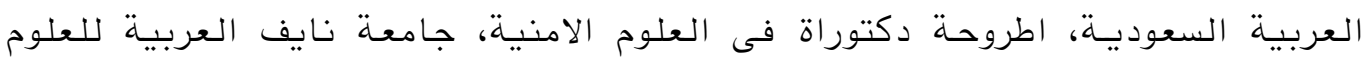

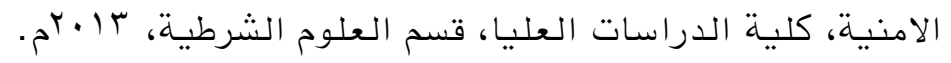

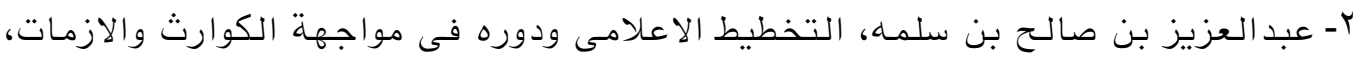

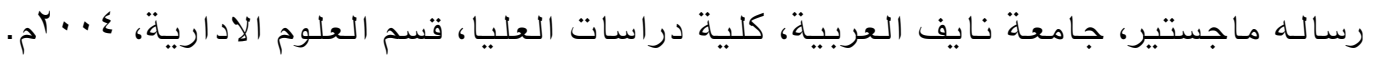

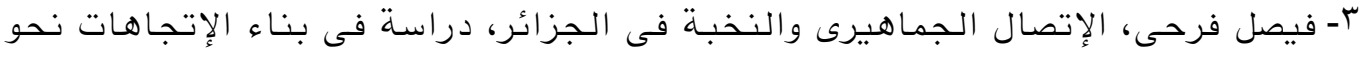

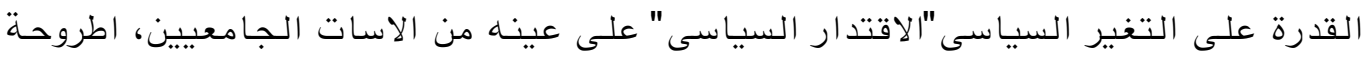

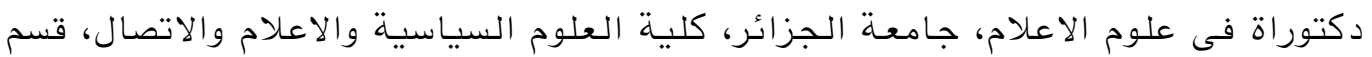

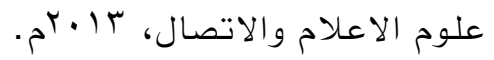

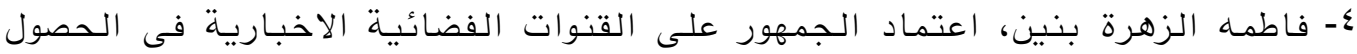

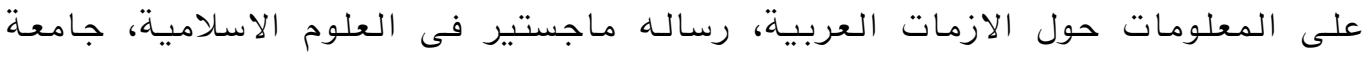

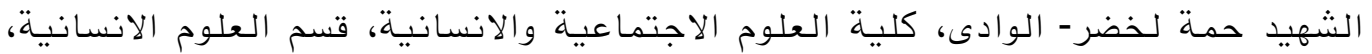

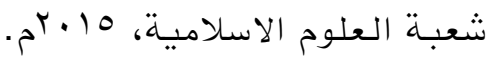

DOI: $10.33193 /$ JALHSS.38.15 